\title{
The role of seasonal flowering responses in adaptation of grasses to temperate climates
}

\author{
Siri Fjellheim ${ }^{1}$, Scott Boden ${ }^{2}$ and Ben Trevaskis ${ }^{2}$ * \\ ' Department of Plant Sciences, Norwegian University of Life Sciences, Ås, Norway \\ ${ }^{2}$ Division of Plant Industry, Commonwealth Scientific and Industrial Research Organisation, Canberra, ACT, Australia
}

\section{Edited by:}

Maria Von Korff Schmising, Max

Planck Society, Germany

\section{Reviewed by:}

lain Robert Searle, The University of Adelaide, Australia

Wilma Van Esse, Max Planck Institute for Plant Breeding Research, Germany

\section{${ }^{*}$ Correspondence:}

Ben Trevaskis, Division of Plant Industry, Commonwealth Scientific and Industrial Research Organisation, GPO Box 1600, Canberra, ACT 2601, Australia

e-mail:ben.trevaskis@csiro.au
Grasses of the subfamily Pooideae, including important cereal crops and pasture grasses, are widespread in temperate zones. Seasonal regulation of developmental transitions coordinates the life cycles of Pooideae with the passing seasons so that flowering and seed production coincide with favorable conditions in spring. This review examines the molecular pathways that control the seasonal flowering responses of Pooideae and how variation in the activity of genes controlling these pathways can adapt cereals or grasses to different climates and geographical regions. The possible evolutionary origins of the seasonal flowering responses of the Pooideae are discussed and key questions for future research highlighted. These include the need to develop a better understanding of the molecular basis for seasonal flowering in perennial Pooideae and in temperate grasses outside the core Pooideae group.

\section{Keywords: flowering, adaptation, biological, evolution, molecular, seasonality, Pooideae}

\section{OVERVIEW}

Grasses from the Pooideae subfamily, family Poaceae, occur widely in temperate regions (Hartley, 1973). In addition to being important ecologically this group includes economically important pasture grasses and cereal crops, as well as invasive species and weeds. Adaptations that allow Pooid grasses to survive the seasonal extremes of temperate climates are of interest since these are central to the success of this sub-family across temperate zones. Such adaptations are also important to agriculture and are critical to the success of temperate cereal crops including wheat, barley, oats, and rye.

A key factor underlying the adaptation of grasses to temperate climates is timing. Timing biological events to occur during specific seasons is the basis for stress avoidance strategies. For example, delaying flowering until after winter allows many grasses to avoid frost damage to cold sensitive reproductive organs (see Fowler et al., 1996). Alternatively, activation of tolerance mechanisms at particular times of year can prime plant physiology for predictably harsh seasonal conditions before these occur. An example of seasonally timed tolerance is the cold acclimation response, where freezing tolerance increases during autumn to maximize chances of winter survival (Thomashow, 2010).

The study of the seasonal timing of biological phenomena is known as phenology. The broad topic of this review is the contribution of phenology to the success of Pooideae in temperate climates. We will highlight how different seasonal cues can adjust the developmental program of grasses to match seasonal cycles, using temperate cereals as examples, and then examine how naturally occurring variation in these responses drives adaptation to different geographical regions and climates. Then we will discuss how the molecular pathways controlling the seasonal flowering responses of temperate grasses might have evolved.

\section{DEVELOPMENTAL PHASES OF TEMPERATE CEREALS AND GRASSES}

The developmental phases of temperate cereals and related temperate grasses can be divided into two broad stages: vegetative and reproductive. During the vegetative phase the shoot apex produces only leaf primordia. Then, when the transition to reproductive growth occurs, inflorescence primordia develop above leaf primordia at the apex. This stage is referred to as inflorescence initiation (Evans, 1964). Subsequently the inflorescence primordia develop into lateral inflorescence branches, called spikelets, whereas the development of the leaf primordia ceases (Figure 1). As inflorescence development proceeds floral primordia appear on the developing spikelets and these develop into flowers, referred to as florets (see Barnard, 1964). Various arrangements of spikelet number, branch length, and floret number exist, giving rise to diverse inflorescence shapes, from compact spikes (e.g., wheat and barley) to panicles (e.g., oats). Internodes beneath the developing inflorescence elongate to form the stem, carrying the inflorescence upwards inside a sheath of leaves. The inflorescence emerges from the leaf sheath shortly before anthesis. In annual grasses the transition from vegetative to reproductive development occurs once. The situation for perennial grasses is more complex and will be discussed later.

\section{SEASONAL REGULATION OF DEVELOPMENT PHASES IN TEMPERATE GRASSES}

The different developmental phases of temperate grasses (limited to Pooid grasses in this review) are timed to optimally coordinate the plant life cycle with the changing seasons. This timing is achieved through the influence of seasonal changes in temperature and daylength on specific points in the developmental program (Figure 1). Initially there is a delay of inflorescence initiation prior to winter. This delay is removed when plants over-winter, 


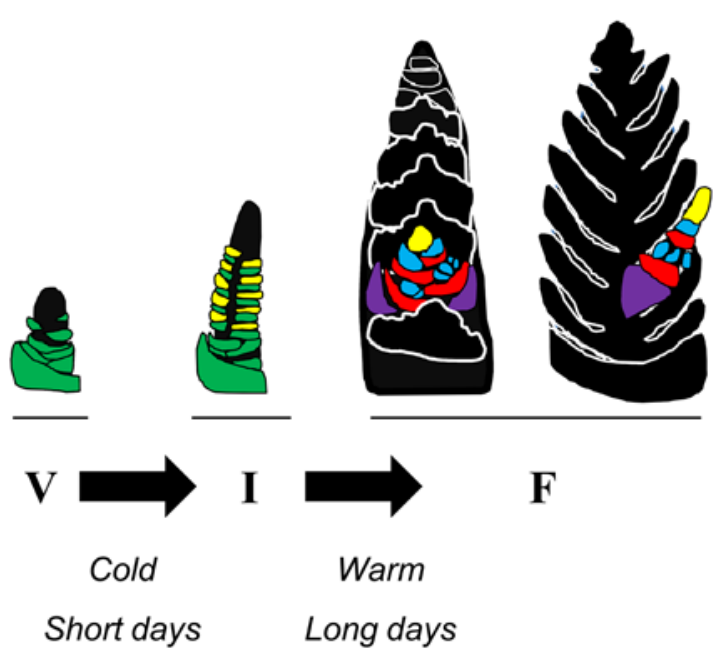

FIGURE 1 | Schematic representation of how seasonal conditions influence the developmental transitions of wheat. At the beginning of the crop life cycle there is a vegetative meristem at the tip of the shoot apex of the main tiller. Leaf primordia (green) develop below the meristem. During winter short days or prolonged cold can promote the transition to reproductive development. This allows inflorescence initiation (I) to occur. The shoot apex elongates and inflorescence primordia (yellow) appear above each of the leaf primordia. During subsequent stages of inflorescence development the lateral inflorescence meristems develop into branches (the spikelets) upon which florets develop, whereas development of leaf primordia ceases. During spring long days and high temperatures can accelerate inflorescence development. Two orientations of the developing inflorescence are represented ( $\mathrm{F}$, floral development) with a single spikelet highlighted and the rest of the spike shown in silhouette. Each spikelet has 2 glumes (purple) and then a series of florets at an early stage of development. The lemma primordia (red) and floral organ primordia (anther primordia, blue) are shown, along with the lateral inflorescence meristem at the end of the spikelet (yellow). Each unit of lemma and floral organ primordia will differentiate into a floret.

allowing inflorescence initiation to occur. Subsequently, increasing daylength and warmer temperatures accelerate development of the inflorescence in spring (Purvis, 1934; Evans, 1964). The overall combination of these seasonal developmental responses ensures that plants remain vegetative before winter, avoiding frost damage to developing reproductive organs, but then flower rapidly in spring, to allow flowering and seed production before the onset of heat and water limitation in summer.

\section{THE RELATIONSHIP BETWEEN DEVELOPMENTAL PHASES AND OTHER TRAITS}

Seasonal timing of developmental phases influences other traits. Sometimes this is simply a matter of timing. For example, if there is limited water at the end of the growing season the timing of flowering (heading date) will influence grain yield of cereal crops because early flowering lines can produce grain before water becomes limiting whereas late flowering lines encounter drought stress, which reduces yield. There are many field studies that demonstrate indirect effects caused by the timing of flowering (Kuchel et al., 2007, for example). In other instances there is a direct relationship between development and other traits. The best understood example is the relationship between flowering and frost tolerance in wheat and barley. During the vegetative growth phase wheat and barley plants can acclimate to cold if exposed to non-freezing low temperatures for a period of weeks and will subsequently survive extreme winter conditions. This capacity to acclimate to cold decreases as plants develop toward flowering (Fowler et al., 2001; Limin and Fowler, 2006). Thus, seasonal regulation of development coordinates the potential for cold acclimation with seasonal conditions; vegetative plants can acclimate to cold during autumn and winter, but this capacity is lost as plants begin to flower in spring, when there is less risk of frost. The influence of developmental phases on the seasonal activation of abiotic and biotic stress tolerances is an important component of the adaptation of grasses to temperate climates.

\section{MOLECULAR PATHWAYS CONTROLLING SEASONAL FLOWERING RESPONSES IN Arabidopsis}

Arabidopsis (Arabidopsis thaliana) is adapted to temperate climates and, like temperate grasses, flowers in response to vernalization (the prolonged cold of winter) and long days (see Amasino, 2010). Arabidopsis provides a useful guide to the types of genes/proteins that regulate flowering and, although there are important differences, the molecular mechanisms controlling seasonal flowering responses of grasses can be viewed as variations of those that also occur in Arabidopsis.

Seasonal flowering of Arabidopsis is controlled through regulation of the floral transition, the point when the floral primordia appear at the shoot apex and flowering begins. In winter annual Arabidopsis ecotypes the floral transition is delayed until plants experience vernalization. This delay is caused by FLOWERING LOCUS C (FLC), which encodes a MADS box transcription factor that represses flowering (Michaels and Amasino, 1999; Sheldon et al., 1999). FLC is expressed at high basal levels prior to vernalization (Michaels and Amasino, 1999; Sheldon et al., 1999). Prolonged exposure to cold represses transcription of FLC, through mechanisms that act at the chromatin of the FLC gene to limit transcription. For example, tri-methylation of histone-3-lysine $27(\mathrm{H} 3 \mathrm{~K} 27 \mathrm{Me} 3)$ in nucleosomes at the FLC locus is required to maintain repression of FLC in vernalized plants (Bastow et al., 2004; Schubert etal., 2006; Finnegan and Dennis, 2007). Stable repression of FLC after vernalization provides a molecular memory of winter. Genetic variation in FLC activity, either due to mutations in the FLC gene itself or in regulators of FLC expression, can reduce or eliminate the ancestral vernalization requirement of Arabidopsis and adapt ecotypes to different climates (see Amasino, 2010).

Long days accelerate the floral transition of Arabidopsis. The long-day flowering response depends on an internal timekeeping mechanism, the circadian clock, which activates expression of CONSTANS (CO) in the late afternoon (Suarez-Lopez et al., 2001). The CO protein is stable in light (Valverde et al., 2004). Thus, when days are long $C O$ expression coincides with light and the protein is active. This activates transcription of FLOWERING LOCUS T $(F T)$ in the leaves. FT encodes a phosphatidyl-ethanolamine binding protein (PEBP) that is translocated through the phloem from the leaves to the shoot apex (Kardailsky et al., 1999; Kobayashi et al., 1999; Corbesier et al., 2007). At the shoot apex the FT protein interacts with FLOWERING LOCUS D, a bZIP transcription 
factor (Abe et al., 2005; Wigge et al., 2005). The resulting complex activates transcription of genes that promote floral development, including $A P 1$, thus triggering the floral transition. Activation of FT by $\mathrm{CO}$ is likely to be mediated through interactions with nuclear factor Y proteins (NF-Y) - also known as heme activator proteins (HAP) or CCAAT binding factors (referred to hereafter as NF-Y proteins; Ben-Naim et al., 2006; Wenkel et al., 2006). These are components of a conserved eukaryotic transcriptional activation complex. Interactions between $\mathrm{CO}$ and NF-Y proteins are mediated by the CCT domain; a protein domain first identified in CO, CO-like and TIMING OF CAB1 EXPRESSION1 proteins (Wenkel et al., 2006). Long-day activation of FT is suppressed in Arabidopsis plants that have not been vernalized (Lee et al., 2000; Michaels et al., 2005). This is due to direct repression of by FLC, which binds to the intron of the FT gene (Helliwell et al., 2006).

High temperatures $\left(>25^{\circ} \mathrm{C}\right)$ can activate expression of $F T$ in short days and accelerate the floral transition (Blázquez et al., 2003; Balasubramanian et al., 2006; Turck et al., 2008). Elevated temperatures during the night activate FT expression. Activation of FT by high-temperatures is largely independent of $C O$ and instead PHYTOCHROME-INTERACTING FACTORS (PIF4 and PIF5) are required (Kumar et al., 2012; Thines et al., 2014). The FLC-like gene FLOWERING LOCUS M1 (FLM1) has also been implicated in the regulation of the high-temperature flowering response of Arabidopsis (Balasubramanian et al., 2006). This gene is differentially spliced in a temperature dependent manner, producing a splice variant that represses flowering at lower temperatures (Lee et al., 2013; Posé et al., 2013).

As outlined in the next section, many of the classes of genes/proteins that regulate seasonal flowering responses in Arabidopsis also play important roles in regulating reproductive development in cereals. There are, however, few direct overlaps between Arabidopsis and cereals, with fundamental differences in the physiology of seasonal flowering responses and in the underlying molecular networks.

\section{MOLECULAR NETWORKS CONTROLLING SEASONAL FLOWERING RESPONSES IN TEMPERATE CEREALS}

There exists considerable diversity in seasonal flowering responses amongst temperate cereals. Some lack the requirement for vernalization, others are daylength insensitive. For the purpose of this review we will consider the presence of a vernalization requirement combined with daylength sensitivity as being the archetypal flowering behavior of temperate cereals. This view is supported by molecular evidence (see subsequent sections) that reduced vernalization requirement and reduced daylength sensitivity are acquired states that have arisen on multiple occasions through mutation.

\section{THE VERNALIZATION REQUIREMENT DELAYS INFLORESCENCE INITIATION BEFORE WINTER}

A core feature of the flowering behavior of temperate cereals and related grasses is the delay of inflorescence initiation before winter; the vernalization requirement. For example, many wheats and barleys will grow vegetatively for extended periods and will not flower without overwintering. Genetic studies of wheat and barley have identified the VRN2 locus as a key gene controlling vernalization requirement in the cereals (Takahashi and Yasuda, 1971). Duplicated zinc finger-CCT domain proteins are found at the VRN2 locus (Yan etal., 2004a). Some accessions of barley and diploid wheats lack a functional copy of VRN2 due to loss-of-function mutations in the VRN2 coding sequence or due to naturally occurring deletions of the entire VRN2 locus (Yan et al., 2004a; Dubcovsky et al., 2005). These accessions can undergo rapid inflorescence initiation without vernalization. This only occurs in long days, however, where rapid flowering is associated with elevated expression FT-like 1 (FT1), the functional equivalent of FT in cereals (Karsai etal., 2005; Turner et al., 2005; Hemming etal., 2008). This suggests that the normal role for VRN2 is to block long-day induction of FT1. Consistent with this hypothesis, transcription of VRN2 occurs in long days (12 h light or longer) and constitutive expression of VRN2 down-regulates FT1 (Trevaskis etal., 2006; Hemming et al., 2008). The VRN2 protein is distantly related to $\mathrm{CO}$ and, like $\mathrm{CO}$, can interact with NF-Y proteins via a CCT domain (Li et al., 2011). Binding of VRN2 to NF-Y proteins might inhibit transcription of FT1 by blocking binding of other CCT domain proteins that normally activate transcription of FT1, such as the cereal CO homologs.

\section{SHORT DAYS ALLOW INFLORESCENCE INITIATION}

Cereal varieties that are unable to flower without vernalization when grown in long days can flower in short days, suggesting that inhibition of inflorescence initiation is weaker in short days (Evans, 1987). This is also evidenced by "short-day vernalization," where plants grown in short days for several weeks will flower when shifted to long-days (Purvis and Gregory, 1937). Low-levels of VRN2 expression in short-days might allow inflorescence initiation in short-days (Dubcovsky et al., 2006; Turner et al., 2013). This is unlikely to occur through FT1, which is expressed mainly in long days. Another FT-like gene (FT3) might be important. FT3 is normally expressed in short but not long days, and lossof-function mutations in FT3 delay flowering primarily in short days (Faure et al., 2007; Kikuchi et al., 2009). Interestingly, FT3 is expressed at high levels in long days in lines that lack VRN2. So daylength specificity of FT3 expression might be mediated by VRN2 (Casao et al., 2011). It is not known whether loss-offunction mutations in FT3 block the short-day vernalization effect. The mechanisms controlling inflorescence initiation in short-days are an interesting area for future research.

\section{THE PROLONGED COLD OF WINTER PROMOTES INFLORESCENCE INITIATION}

Prolonged exposure to low-temperatures (vernalization) promotes inflorescence initiation (Chouard, 1960). Vernalization can be applied to imbibed seeds or to actively growing plants and is effective irrespective of daylength, even in total darkness (Gassner, 1918; Gott et al., 1955). The effect of vernalization on plant development can be separated from the actual low-temperature treatment. For example, vernalization of imbibed seeds promotes rapid inflorescence initiation when plants are subsequently shifted to normal glasshouse conditions (Sasani et al., 2009, for example). Thus, there is a memory of prolonged cold treatment. Typically temperatures between 0 and $10^{\circ} \mathrm{C}$ are effective for vernalization 
and the effect of cold is quantitative, with longer cold treatments causing more rapid inflorescence initiation until a point when further cold causes no further reduction in the time taken to flower; the vernalization saturation point (Gassner, 1918; Gott et al., 1955).

The promotion of inflorescence initiation by vernalization is stronger than the effect of short days. For example, in experiments performed by Allard et al. (2012) wheat plants exposed to prolonged low-temperatures $\left(5^{\circ} \mathrm{C}\right.$ for 30 days) flowered with 8 leaves (primary tiller). Typically there are four to five leaf primordia present at the time of germination and these develop into leaves irrespective of conditions during subsequent growth, so a final leaf number of 8 is indicative of a rapid progression toward flowering. In comparison, plants grown without vernalization in long days flowered with 16 leaves. Plants grown in short days for 3-10 weeks then shifted to long days flowered with 12 leaves, showing that short days can promote inflorescence initiation, though the effect is weaker than that of prolonged cold (12 leaves following short day treatment versus 8 leaves after vernalization). At a broader level the effect of prolonged cold (vernalization sensu stricto) is profoundly different to that of short-day treatment because vernalization at low temperatures slows growth. This is particularly evident with vernalization of imbibed seeds where plants can emerge from prolonged cold treatment with only one or two expanded leaves. In comparison plants exposed to several weeks of short days will have many leaves on the main stem and also secondary tillers. Thus, the term "short-day vernalization" should be interpreted with caution, as noted by Evans (1987) who preferred the term "short-day induction."

The central gene controlling vernalization in cereals is VERNALIZATION1 (VRN1), a MADS box transcription factor gene related to the AP1/FRUITFULL genes of Arabidopsis (Danyluk et al., 2003; Trevaskis et al., 2003; Yan et al., 2003; Trevaskis, 2010). VRN1 promotes inflorescence initiation but is expressed at low levels prior to vernalization and this limits the rate of progression toward inflorescence initiation (Danyluk et al., 2003; Murai etal., 2003; Trevaskis etal., 2003; Yan etal., 2003). Exposure to low temperatures induces transcription of VRN1 (Danyluk et al., 2003; Murai et al., 2003; Trevaskis et al., 2003; Yan et al., 2003). This begins rapidly with the onset of cold, within $12 \mathrm{~h}$, but initial expression is weak and several weeks of cold are required to elevate $V R N 1$ transcript levels to a level that promotes rapid inflorescence initiation (Sasani et al., 2009; Oliver et al., 2013). There is a strong relationship between the length of cold experienced, VRN1 expression levels, and the degree to which inflorescence initiation is accelerated post-vernalization (Sasani et al., 2009). These observations are all consistent with a model where stable induction of VRN1 provides a quantitative memory of vernalization (Trevaskis et al., 2007; Trevaskis, 2010). Indeed, transcriptome analyses show that VRN1 is one of a limited number of genes that show lasting changes in expression levels in response to seed vernalization (Greenup et al., 2011). Low temperatures induce changes in histone modification of nucleosomes associated with VRN1, which might provide a mechanism for stable activation of this gene (Oliver et al., 2009, 2013).
Mutations that disrupt VRN1 function greatly reduce the impact of vernalization, supporting a central role for VRN1 in the vernalization response (Chen and Dubcovsky, 2012). Conversely, naturally occurring mutations in the promoter or large insertions/deletions in the first intron of VRN1 are associated with elevated basal transcription and cause rapid flowering without vernalization (Yan etal., 2004b; Fu etal., 2005). These mutations have been used to breed and select cereal cultivars with reduced vernalization requirement, which are grown in regions or at times of year when vernalization does not occur (see below).

\section{LONG DAYS ACCELERATE INFLORESCENCE DEVELOPMENT AFTER VERNALIZATION}

Daylength can influence both the timing of inflorescence initiation and the rate of inflorescence development after vernalization. In long days vernalized plants will progress rapidly through inflorescence initiation and subsequent stages of inflorescence development until head emergence and anthesis. In short days inflorescence initiation occurs, though not as rapidly as in long days, and thereafter inflorescence development occurs slowly and there is a strong delay of head emergence and anthesis (e.g., Limin and Fowler, 2006; Sasani et al., 2009).

Although long days can accelerate inflorescence initiation in glasshouse experiments this is unlikely to occur in the field for autumn sown varieties (vernalization requiring cultivars, see comments above regarding archetypal flowering behavior), which typically undergo inflorescence initiation in short days toward the end of winter. Instead longer days are likely to coincide with the inflorescence development and stem elongation stage (Figure 1). Daylength shift experiments, where wheat plants are shifted from short to long days, or vice versa, at different time points, show that the time from inflorescence initiation to the point when the terminal spikelet develops is a critical window for the acceleration of inflorescence development by long daylengths (Miralles and Richards, 2000).

Key genes controlling the long-day flowering response are PHOTOPERIOD1 (PPD1) and FT, the cereal FT equivalent (Turner etal., 2005; Shaw etal., 2012). Expression of FT1 is induced by long days, analogous to FT in Arabidopsis, and it seems that the role for the FT protein as a leaf expressed mobile flowering signal is conserved in cereals (Turner et al., 2005; Tamaki etal., 2007). Long-day induction of FT1 requires PPD1. PPD1 encodes a pseudo response regulator related to components of the circadian clock and includes a CCT domain that can interact with NF-Y complexes, similar to CO (Turner etal., 2005; Li et al., 2011). Transcription of PPD1 follows a distinctive diurnal profile, though current models suggest that PPD1 does not play a role in circadian clock per se, and instead regulates outputs of the clock under long days to induce expression of FT1 (Turner etal., 2005; Campoli et al., 2012).

Deletions in the promoter of the wheat PPD1 gene are associated with elevated transcript levels of this gene at night, in short daylengths (Beales et al., 2007). These deletions are linked to elevated FT1 expression and reduced long-day requirement 
(photoperiod insensitivity), such that plants flower early irrespective of daylength (Beales et al., 2007). Mutations that alter circadian clock rhythms can also up regulate FT1 and reduce photoperiod sensitivity, loss of EARLY FLOWERING 3 (ELF3, MAT.a8) or PHYTOCLOCK1/LUX1 function, for example (Faure etal., 2012; Mizuno etal., 2012; Zakhrabekova etal., 2012; Campoli et al., 2013; Gawroñski et al., 2014). Genetic activation of the FT1 gene itself reduces daylength sensitivity, triggering constitutive early flowering (Yan et al., 2006). Activation of FT1 can also bypass the normal requirement for vernalization; a strongly active allele of this gene was first identified as Spring Growth Habit 3 , a locus linked to reduced vernalization requirement (subsequently named VRN3; Takahashi and Yasuda, 1971; Yan et al., 2006). This active allele has increased FT1 gene copy number (four copies), which might cause increased transcriptional activity (Nitcher et al., 2013). A recent study suggests that structural alterations also occur amongst the four gene copies in this allele, so the exact cause of increased FT1 transcription remains unclear (Loscos et al., 2014).

The FT1 protein of wheat interacts with FD-like proteins, analogous to FT and FD in Arabidopsis ( $\mathrm{Li}$ and Dubcovsky, 2008). This is likely to activate expression of AP1like genes at the shoot apex, including VRN1 but also two other AP1-like genes (Preston and Kellogg, 2008). FT1 also interacts with FDL2 in leaves (Li and Dubcovsky, 2008). This potentially allows long-day induction of VRN1 in leaves. This pathway operates in cereal varieties where activation of FT1 triggers inflorescence initiation without prior vernalization, such as those that lack VRN2 or that carry active FT1 (VRN3) alleles (Yan etal., 2006; Hemming et al., 2008; Shimada etal., 2009). Long-day induction of VRN1 via FT1 is unlikely to play a major role in triggering inflorescence initiation in response to vernalization, however, since VRN1 is expressed at high levels in leaves and at the shoot apex of vernalized plants irrespective of daylength (Sasani et al., 2009). It is possible that a FT-FD dependent pathway might activate expression VRN1 after short-day induction, or activate expression of other AP1-like genes in the leaves of vernalized plants.

Gibberellins play a role in the long-day flowering response of grasses (King and Evans, 2003). A shift to long days can trigger a rapid increase of gibberellin biosynthesis in leaves and application of gibberellins can accelerate inflorescence development in short days, mimicking the effect of longer daylengths (Evans et al., 1990; King et al., 2006). Leaf produced gibberellins might act as florigens in grasses, providing a mobile florigenic signal that is transported from the leaves to shoot apex to accelerate flowering, in addition to the FT protein (King and Evans, 2003). Applying gibberellins only accelerates inflorescence development when applied to vernalized plants or to accessions that carry active alleles of VRN1, placing the gibberellin response downstream of vernalization (MacMillan et al., 2005; Pearce et al., 2013; Boden et al., 2014). Paclobutrazol, an inhibitor of GA biosynthesis, slows the constitutive early flowering of ELF3 loss-of-function mutants in short days without influencing FT1 expression (Boden et al., 2014). This shows that gibberellins likely act parallel to, or downstream of, FT1.

\section{HIGH TEMPERATURES ACCELERATE INFLORESCENCE DEVELOPMENT IN LONG DAYS}

Elevated growth temperatures can accelerate flowering of cereals. This occurs in long days, where elevated temperatures accelerate inflorescence development (Rawson and Richards, 1993). In short days high temperatures have the opposite effect, slowing inflorescence development (Rawson and Richards, 1993; Hemming et al., 2012). The acceleration of inflorescence development by high temperatures when days are long makes sense in a seasonal context, since this would further accelerate flowering toward the end of spring and allow grain production to occur more rapidly in warmer conditions that might accompany increased risk of heat stress and water limitation. Overall the physiology of the high-temperature flowering response in cereals is markedly different to that of Arabidopsis; accelerating inflorescence development post-initiation in long days, versus promoting floral initiation in short days.

Gene expression studies suggest that neither FT1 nor other FTlike genes are high-temperature responsive in cereals (Hemming et al., 2012). Furthermore, activation of FT1 by miss-expression of PPD1 or by mutations in components of the circadian clock do not allow high-temperatures to accelerate inflorescence development in short-days (Hemming et al., 2012). This suggests that FT1 is not the long-day activated factor that allows high-temperature acceleration of inflorescence development. Instead, it seems that an as yet unidentified long-day activated pathway allows high-temperatures to accelerate inflorescence development.

Transcriptome analyses have been used to identify hightemperature responsive developmental regulators in barley (Hemming etal., 2012). A series of genes thought to act downstream of VRN1 in the vernalization response show altered expression at elevated temperatures, including the MADS box gene ODDSOC2 (Hemming et al., 2012). This gene has no direct equivalent in Arabidopsis but might be related to the FLC gene family (Ruelens et al., 2013). ODDSOC2 is down-regulated in vernalized barley plants and represses flowering when expressed constitutively, likely through down-regulation of FLOWERING PROMOTER FACTOR1-like genes (FPF1-like; Greenup et al., 2010). ODDSOC2 is expressed at elevated levels when vernalized plants are grown at high temperatures (constant $25^{\circ} \mathrm{C}$ ) in short-days, where inflorescence development is retarded (Hemming et al., 2012). This highlights a potentially interesting parallel with the role of FLC-like MADS box genes (FLM) in regulating temperature responses in Arabidopsis and other plants (Lee et al., 2013; Posé et al., 2013). FPF1-like genes, a potential downstream target of ODDSOC2, also show temperature-responsive expression in barley (Hemming et al., 2012). Further research is required to confirm a role for ODDSOC2 and FPF1-like genes in regulating temperature-induced flowering responses of cereals.

\section{MAPPING MOLECULAR NETWORKS CONTROLLING SEASONAL FLOWERING: CONSIDERATIONS FOR CEREALS VERSUS Arabidopsis}

As outlined above, multiple pathways controlling developmental responses to seasonal cues are integrated to determine the timing of a single developmental transition in Arabidopsis. These 
pathways can be mapped together as a single network. The situation is more complex in grasses, where seasonal cues have varying effects at different developmental stages and/or different times of year. We suggest that molecular pathways controlling seasonal developmental responses in grasses should be considered in a developmental stage and season specific manner (Figure 2). The concept of sub-dividing networks controlling developmental responses to specific phases/seasons is also important for the development of gene based models to predict flowering behavior of cereals and related grasses (Brown et al., 2013).

\section{VARIATION IN FLOWERING BEHAVIOR ADAPTS CEREALS TO DIFFERENT GEOGRAPHICAL REGIONS}

Diversity in the VRN1 gene is a major driver of variation in vernalization requirement in temperate cereal crops. Different mutations in the promoter, insertions or deletions in the first intron, amino acid substitutions and copy number variation all occur at the VRN1 locus (Table 1). Similar, though not identical, variation occurs in non-domesticated wheats, so variation in vernalization requirement mediated by VRN1 occurs independently of crop domestication (Golovnina et al., 2010).

The extent of diversity in VRN1 suggests that variation in this gene might be useful to adapt accessions to different environments and there is strong historical evidence that this is the case. The history of the Australian wheat industry provides an excellent example. The first wheats grown in Australia were English wheats that required both vernalization and long days to flower rapidly. These wheats were ill-suited to warm Australian growing environments, taking too long to flower in the field, and suffered from end of season heat stress and water limitation, and also strong disease pressure (see Evans, 1980; Eagles et al., 2009). In the late 19th century William Farrer had the foresight to realize that selective breeding could be used to improve the adaptation of Australian wheats. He imported early flowering wheats from India, which he then crossed with European wheats to select better adapted strains. His first cultivar "Federation" was released in 1901 and proved enormously successful. Indeed, the germplasm he developed was the basis for adaptation of Australian wheat cultivars until the 1960s (see Eagles et al., 2009). Molecular characterization of the Australian wheat pedigree, using

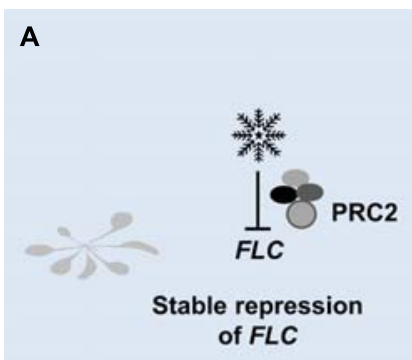

B

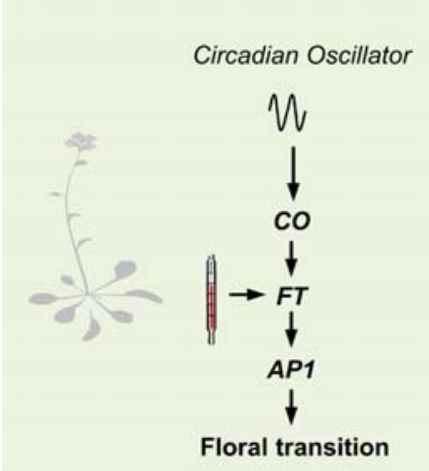

C

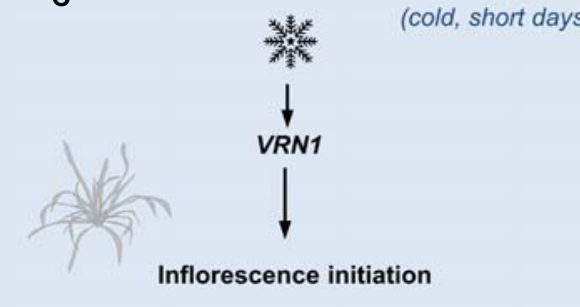

D

Spring (warm, long days)

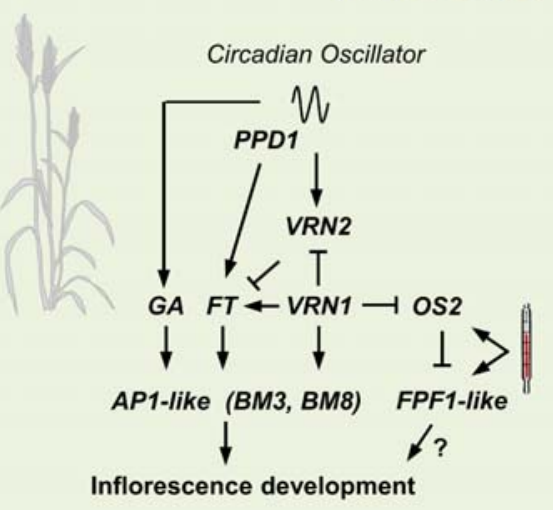

FIGURE 2 | An overview of pathways controlling seasonal flowering responses in grasses contrasted with those in Arabidopsis. (A) The prolonged cold of winter (snowflake) triggers lasting repression of FLOWERING LOCUS C (FLC) in Arabidopsis, via the Polycomb Repressor Complex 2 (PRC2). (B) The long days of spring activate expression of FLOWERING LOCUS T, a process mediated by the circadian oscillator via CONSTANS (CO). FT activates expression of genes such as a APETALA1 that trigger floral development. High-temperatures (thermometer) can also activate expression of $F T$ to accelerate flowering. (C) Winter cold activates expression of VERNALIZATION1 (VRN1) in cereals and related grasses. VRN1 promotes inflorescence initiation at the shoot. (D) VRN1 remains active after winter and down-regulates VRN2, which would otherwise repress the long-day flowering response in leaves. As daylength increases after winter, expression of FT-like 1 is activated by the circadian oscillator, via PHOTOPERIOD1. Long days also activate gibberellin (GA) biosynthesis. The long-day flowering response activates expression of genes at the shoot apex that promote the development of floral organs. These include other AP1-like genes (BM3 and BM8 in barley for example). High temperatures accelerate the long-day response, possibly via FLOWERING PROMOTER1-like genes (FPF1). 
Table 1 | Variation in the VRN1 gene of cultivated cereals.

\begin{tabular}{|c|c|c|c|}
\hline Variation & Genome & Effect & Reference \\
\hline Promoter mutations, insertion deletions & $A^{m}$ & Elevated expression, Reduced vernalization req. & Yan et al. (2003) \\
\hline Large deletions, first intron & $A, B, D, H$ & Elevated expression, Reduced vernalization req. & $\begin{array}{l}\text { Fu et al. (2005), } \\
\text { Oliver et al. (2013) }\end{array}$ \\
\hline Insertion, first intron & $H$ & Elevated expression, Reduced vernalization req. & $\begin{array}{l}\text { Cockram etal. (2007), } \\
\text { Stockinger et al. (2007), } \\
\text { Oliver etal. (2013) }\end{array}$ \\
\hline Promoter SNP (and intron deletion) & $\mathrm{D}$ & Reduced expression, Increased vernalization req. & Zhang et al. (2012) \\
\hline CNV $(3 \mathrm{x})$, coding region SNP & A & Reduced expression, Increased vernalization req. & $\begin{array}{l}\text { Chen etal. (2009), } \\
\text { Díaz et al. (2012) }\end{array}$ \\
\hline CNV $(2 x)$ with promoter insertion & A & Elevated expression, Reduced vernalization req. & Yan et al. (2004b) \\
\hline
\end{tabular}

$A^{\mathrm{m}}=$ Triticum monococcum.

$H=$ Hordeum vulgare.

$A, B, D=$ subgenomes of hexaploid bread wheat (Triticum aestivum).

$C N V=$ copy number variation.

DNA extracted from seeds held in stock centers, shows that the reduced vernalization requirement of Federation was caused by an allele of VRN1 that has a mutation in the promoter (Eagles et al., 2009).

Variation in VRN1 can also increase the duration of vernalization required to trigger rapid flowering. A multi-copy allele of $V R N 1$, with a substitution of a conserved amino acid residue in at least one copy, occurs in winter wheats grown in regions with cold winters (Chen et al., 2009; Díaz et al., 2012; Cane et al., 2013). This allele is associated with low-transcriptional activity and a slow transcriptional response to vernalization, and is linked to increased requirement for vernalization (Díaz et al., 2012). An association screen suggests that frost tolerant wheats have this allele of VRN1 together with an expanded number of C-REPEAT BINDING FACTOR genes at the FROST TOLERANCE 2 locus (Zhu et al., 2014). It seems that variation in $V R N 1$ allows the vegetative growth phase to be lengthened in cultivars grown in regions with extreme winters and this has been co-selected with genes that enhance frost tolerance.

There is also extensive variation in daylength sensitivity amongst cereals (Table 2). In wheat, a constitutive long-day flowering response is mediated mainly by active alleles of PPD1 that allow crops to be grown at times of year or at latitudes where short daylengths would otherwise limit cultivation. For example, breeding programs that are located at low-latitudes and focus on rapid cycling varieties (e.g., International Maize and Wheat Improvement Centre, CIMMYT, Mexico) are likely to select cultivars with photoperiod insensitivity, which allows rapid flowering without long days. Conversely, a mutated version of the barley PPD1 gene occurs in many European barleys (Turner et al., 2005; Jones et al., 2011). These barleys have a reduced response to long-days, which lengthens the growing season and allows more biomass to accumulate, increasing grain yield (see Cockram et al., 2007). Another example of adaptation through altered photoperiod sensitivity is the use of a loss-of-function mutation in the ELF3 gene (MAT.a8) to breed barley cultivars that flower rapidly irrespective of daylength, which are well suited to short summer growing seasons at high latitudes (Lundqvist, 2009; Faure et al., 2012; Zakhrabekova et al., 2012).

Variation that influences development irrespective of environmental cues, often referred to as the EARLINESS PER SE (EPS), has also been utilized in crop breeding. The EPS2 gene (HvCENTRORADIALIS, HvCEN) of barley encodes a PEBP that is distantly related to the FT gene family (Comadran etal., 2012). An amino acid substitution in the HvCEN gene (Ala135 to Pro) delays flowering, and has been used to lengthen the inflorescence development phase of European spring barleys. Conversely, the wildtype allele predominates in autumn sown vernalization responsive barleys (Comadran et al., 2012). Thus, HvCEN1 can be considered as a modifier of seasonal flowering responses.

The examples above highlight how different developmental regulators have been used to modify the crop life cycle to suit the growing environments encountered at particular location and sowing dates. These examples also show that such variation influences the duration of specific developmental phases (Figure 3). Altering the duration of different developmental phases can have profound effects on plant physiology and plant architecture, and strongly influences major components of yield such as grain number per spike and grain size (e.g., Stelmakh, 1993; Eagles et al., 2014). There is now considerable interest in understanding how different combinations of genetic variation in genes controlling flowering behavior can be used to breed cereal varieties that are suited to specific climates but that also have high yield potential (Reynolds et al., 2009).

\section{SEASONAL FLOWERING RESPONSES OF TEMPERATE GRASSES}

Temperate grasses such as poa (Poa sp.), ryegrass (Lolium sp.), fescue (Festuca sp.), and timothy grass (Phleum pretense) flower in response to vernalization and long days, though there is naturally occurring variation in vernalization and daylength requirements 
Table 2 | Variation in the PPD1 gene of cultivated cereals.

\begin{tabular}{|c|c|c|c|}
\hline Variation & Genome & Effect & Reference \\
\hline Promoter deletion & $A, D$ & Reduced long day requirement & Beales etal. (2007), Wilhelm etal. (2009), Shaw et al. (2013) \\
\hline Promoter insertion & A & Reduced long day requirement & Nishida et al. (2013) \\
\hline CNV $(2-4.5 x)$ & B & Reduced long day requirement & Díaz et al. (2012) \\
\hline CCT domain mutation & $\mathrm{H}$ & Reduced long-day response & Turner et al. (2005) \\
\hline Promoter deletion & A & Reduced long-day response & Shaw etal. (2013) \\
\hline Deletion, transcribed sequence & A & Reduced long-day response & Beales etal. (2007), Shaw etal. (2013) \\
\hline Deletion, transcribed sequence & $\mathrm{D}$ & Reduced long-day response & Beales etal. (2007), Shaw etal. (2013) \\
\hline Intron insertion & $\mathrm{D}$ & Reduced long-day response & Beales etal. (2007), Shaw etal. (2013) \\
\hline
\end{tabular}

$H=$ Hordeum vulgare.

$A, B, D=$ subgenomes of hexaploid bread wheat (Triticum aestivum).

$C N V=$ copy number variation.

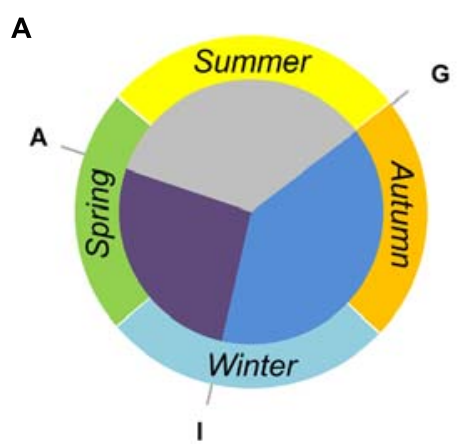

B

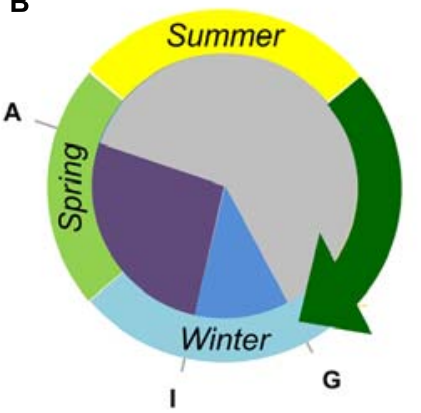

C

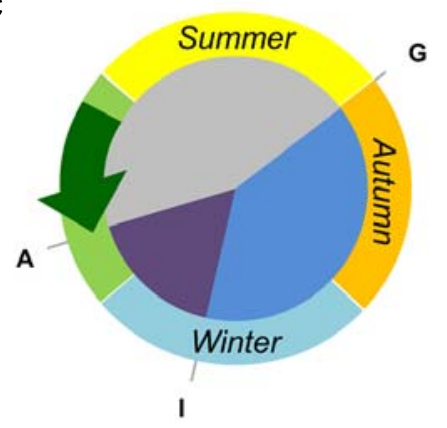

FIGURE 3 | Tailoring the crop life cycle to fit different environments by modifying the duration of discrete developmental phases. (A) $A$ vernalization responsive and daylength sensitive cereal cultivar can be sown and germinate " $\mathrm{G}$ " in early autumn but will remain vegetative until late winter, when inflorescence initiation occurs "I". Anthesis " $A$ " will occur during spring, at a date determined by the photoperiod sensitivity.

(B) A near-isogenic line derived from the hypothetical wheat has reduced vernalization requirement. This line can be sown at a later date and will have a shortened vegetative growth phase (blue sector). Such a line might be useful in regions where there is a late onset of autumn rain, requiring a delayed sowing of crops. (C) A second near-isogenic line has reduced photoperiod sensitivity. This line can be sown in autumn, and still requires vernalization to flower, but will progress through inflorescence development (purple sector) more rapidly in spring. Such a line would be useful where there is a rapid onset of hot/dry conditions, allowing plants to avoid heat and drought stress during the grain filling stage. both between species of specific genera and within populations of individual species (Evans, 1964). The molecular biology of seasonal flowering-responses has been studied in some temperate grasses. Orthologs of VRN1 appear to function in the vernalization responses of perennial ryegrass (Lolium perenne), timothy grass (Phleum pratense), and fescue (Festuca pratensis; Petersen et al., 2004; Andersen et al., 2006; Seppänen et al., 2010; Ergon et al., 2013). The VRN1 ortholog of Brachypodium is also likely to play a key role in maintaining a memory of winter cold (Ream et al., 2014). Similarly, FT1-like genes are likely to play a central role in promoting flowering in response to long days in perennial ryegrass and Brachypodium (King et al., 2006; Lv et al., 2014; Ream et al., 2014). Genetic variation in vernalization requirement or daylength sensitivity has also been linked to VRN1 and FT1-like genes in perennial ryegrass (Jensen et al., 2005; Asp etal., 2011; Skøt et al., 2011; Shinozuka et al., 2013). Thus, knowledge of the molecular pathways controlling seasonal flowering responses in temperate cereals is relevant to Pooid grasses and can provide insights into how variation in genes controlling vernalization and daylength requirements can adapt temperate grasses to different climates or geographical regions.

\section{EVOLUTION OF SEASONAL FLOWERING-RESPONSES IN THE GRASSES}

Most of the $\sim 10,000$ species of the grass family are members of one of two monophyletic clades (groups of species including a single common ancestor and all its descendents). The first clade includes tropical grass subfamilies and is known as the PACMAD (Panicoideae, Arundinoideae, Chloridoideae, Micrairoideae, Aristidoideae, Danthonioideae), of which the Panicoideae subfamily includes crops such as maize (Zea mays), sorghum (Sorghum bicolor), and sugar cane (Saccharum officinarum). The second clade includes the Pooideae subfamily, together with the subfamilies Ehrhartoideae (including rice, Oryza sativa) and Bambusoideae (the bamboos) and is known as the BEP clade, with Bambusoideae widely accepted as the sister group to the Pooideae (Figure 4; Grass Phylogeny Working Group [GPWG] II, 2012; Wu and Ge, 2012; Zhao et al., 2013). Of the grass subfamilies, 


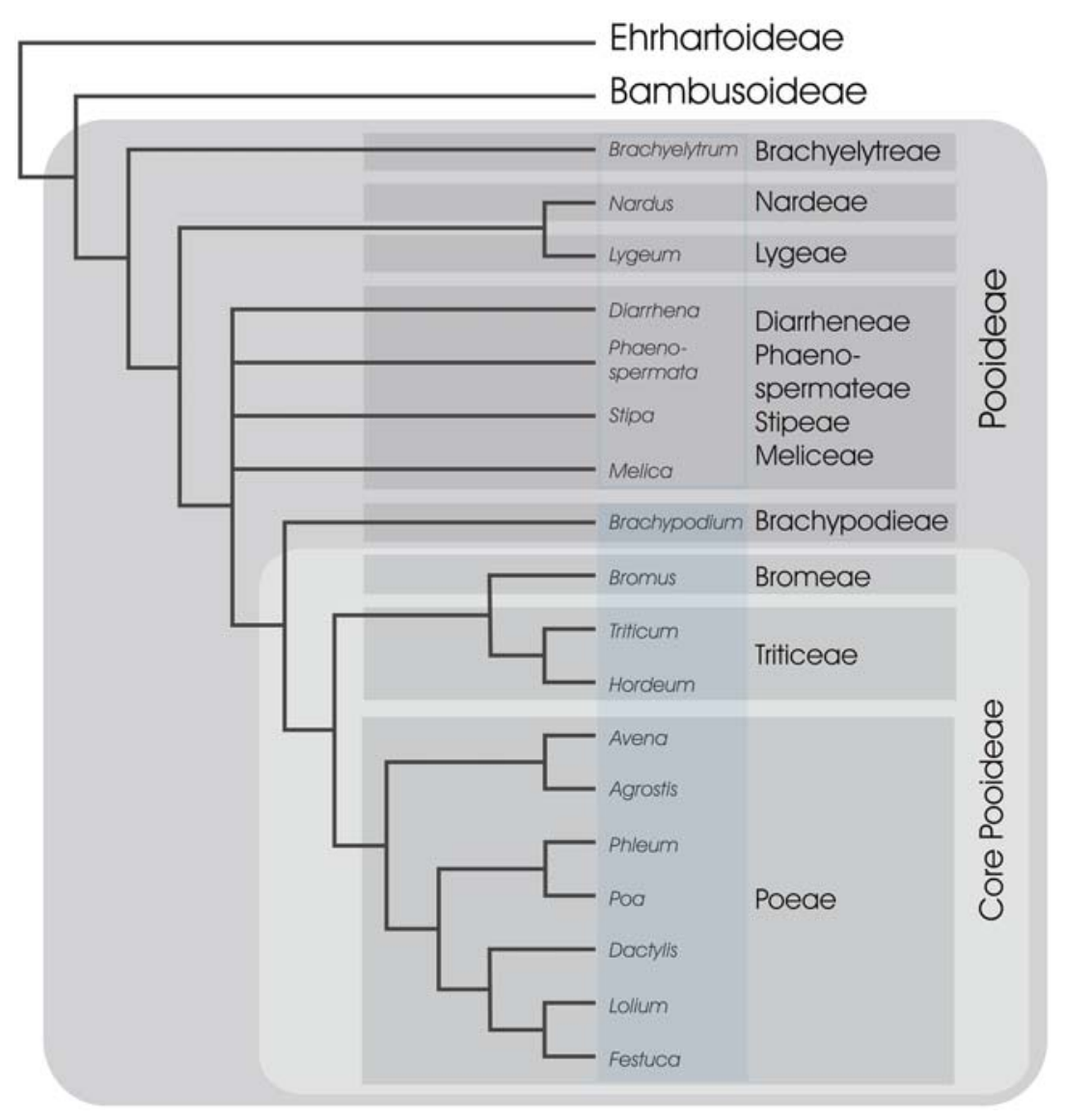

FIGURE 4 | A simplified phylogeny of subfamily Pooideae. Relationships between major tribes of Pooid grasses, represented by selected genera, are shown based on Davis and Soreng (2007) and Schneider et al. (2009). Tribes are in shaded gray boxes and 11 out of 14 tribes are included following classification of Soreng etal. (2000). All genera represented in Brachypodieae, Bromeae, Triticeae, and Poeae are known to have at least some species flowering in response to vernalization and long days (shaded blue rectangle; Fejer, 1966; Sampson and Burrows, 1972; Richardson et al., 1986; Heide, 1994; Schwartz et al., 2010), whereas the remaining genera in Pooideae have unknown flowering requirements (open blue rectangle). The two closest non-Pooideae subfamilies (Ehrhartoideae and Bambusoideae) are also shown (BEP clade).
Pooideae is one of the most species rich and dominates the grass flora in temperate regions with as much as $90 \%$ of the grasses in northern temperate regions belonging to this subfamily (Hartley, 1973).

Current knowledge of the molecular pathways that control flowering of temperate grasses comes from a restricted selection of cereals and pasture grasses, all members of a group informally termed the "core Pooideae" (Davis and Soreng, 1993), or from Brachypodium, the sister group to the core Pooideae (Figure 4). The vernalization response and long-day flowering are conserved features of the core Pooideae and Brachypodium (Figure 4). In contrast, rice does not require vernalization and flowers in response to shorter daylengths, similar to many grasses of the Panicoideae. Thus, it has been hypothesized that the vernalization and longday flowering responses of grasses evolved in an ancestor of the Pooideae.

\section{THE EVOLUTION OF THE VERNALIZATION RESPONSE}

As outlined above, orthologs of the cereal VRN1 gene function in the vernalization responses of temperate grasses such as ryegrass, fescue, and timothy grass (all core Pooids), and the VRN1 gene of Brachypodium seems to have the same function. This suggests that the central role for VRN1 in the vernalization response of temperate grasses evolved early during the radiation of the Pooideae. Vernalization-induced flowering likely co-evolved with increased freezing tolerance (see Sandve et al., 2011).

There are two regulatory features of VRN1 that are likely to have been pivotal to the evolution of the vernalization response in temperate grasses. The first is that activity of VRN1 is maintained at a low basal level before winter to delay inflorescence initiation. The second is low-temperature induction. Low basal activity of VRN1 appears to be mediated by the large $(\sim 10 \mathrm{~kb})$ first intron, which has expanded relative to the equivalent region in the rice ortholog of VRN1 (OsMADS14, $5 \mathrm{~kb}$ first intron; Fu etal., 2005; von Zitzewitz etal., 2005; Szûcs etal., 2007; Hemming etal., 2009; Oliver etal., 2013). Lowtemperature induction of VRN1 seems to be controlled by the promoter, possibly by pathways that activate transcription of other cold-induced genes (Alonso-Peral et al., 2011; Oliver et al., 2013). A deeper understanding how the first intron limits VRN1 
transcription, or of the mechanisms mediating low-temperature induction of $V R N 1$, could potentially contribute to a better understanding of how the vernalization response evolved in grasses.

\section{THE EVOLUTION OF THE LONG-DAY FLOWERING RESPONSE}

One explanation for the evolution of different daylength flowering responses is that the activity of the daylength response can be inverted. For example, the short-day flowering response of rice might have arisen through inversion of activity of the longday response pathway first identified in Arabidopsis. This has been suggested to occur through modification of CO activity (see Simpson, 2003). A similar inversion in the daylength response could also be suggested to account for the evolution of longday grasses from tropical grass ancestors that flowered in short days. We suggest, however, that complete inversions of daylength responses are unlikely to occur because daylength responses influence other aspects of plant physiology aside from flowering time. For example, daylength regulates the rate of starch breakdown during the night so that starch is depleted shortly before dawn (Graf and Smith, 2012). CO strongly influences expression of genes that control diurnal starch metabolism (Ortiz-Marchena et al., 2014). Unlike flowering behavior, daylength regulation of starch metabolism is likely to be conserved between short and long day grasses, which will need similar daylength dependent regulation of starch metabolism. This potentially limits evolutionary flexibility to invert daylength-induced flowering responses by modifying $\mathrm{CO}$ activity.

An alternative model is that a common daylength response mechanism elicits different outputs to trigger flowering under either short or long days in different plants. According to this model a conserved daylength response mechanism operates in all plants. Then, there are both short and long day output pathways that influence flowering, but these have evolved to be stronger or weaker in different lineages (Greenup et al., 2009). For example, the temperate grasses might have evolved to flower in long days through the loss of ancestral genes that accelerated flowering under short days (Greenup et al., 2009).

There are similarities between the molecular pathways controlling daylength responses of rice and temperate cereals that suggest there has not been an inversion of the activity of pathways controlling daylength-induced flowering responses. For example, a VRN2-like gene, GHD7, is expressed in long days in rice, where it represses expression of FT-like genes, similar to VRN2 in the temperate cereals (Xue etal., 2008). In rice plants that lack GHD7 function there is expression of FT-like genes in long-days and this accelerates flowering (Xue et al., 2008). Similarly, the maize (Z. mays) ortholog of GHD7 represses flowering in long-days and a similar function has been suggested for a Sorghum (S. bicolor) equivalent (Ducrocq et al., 2009; Hung et al., 2012). Thus, a role for VRN2-like genes in blocking flowering under long-days occurs across the grass lineage, though is not necessarily related to a vernalization requirement. A recent study of sorghum shows that $\mathrm{CO}$ activates expression of FTlike genes in long-days in lines that lack GHD7, consistent with the idea that $\mathrm{CO}$ activity has not been inverted to repress flowering in long-days in tropical grasses (Yang et al., 2014). The weak inhibition of inflorescence initiation of temperate grasses in short-days also suggests that Pooid grasses retain ancestral pathways that allow flowering under short-days, though these pathways are weaker than the long-day response that is activated in vernalized plants (see Sections "Short Days Allow Inflorescence Initiation" and "The Prolonged Cold of Winter Promotes Inflorescence Initiation”).

Novel daylength regulators might also have evolved to suppress flowering in short-days in the temperate grasses. A novel modifier of the daylength flowering response has been identified in Brachypodium, where a daylength regulated microRNA (miR5200) down-regulates FT1 and FT2 in short days (Wu et al., 2013). This microRNA is expressed in leaves in short days, where it triggers cleavage of FT1 and FT2 mRNA molecules (Wu et al., 2013). Whether similar microRNA molecules are active in other temperate grasses or in cereal crops will be an interesting topic for future research.

\section{ARE PERENNIALS THE MISSING LINK?}

Perenniality occurs throughout the Pooideae (Watson and Dallwitz, 1992) and it seems that monocarpic annual grasses have evolved repeatedly from perennial ancestors. This raises the question of whether evolution of the seasonal flowering responses of the Pooideae should be considered from perennial perspective?

Molecular studies of perennial temperate grasses are less common than those focussed on annual species. The best characterized are perennial ryegrass and timothy grass, which have both been the focus of physiological and molecular studies (MacMillan et al., 2005; Seppänen et al., 2010; Jokela et al., 2013). Like other members of the core Pooideae, perennial ryegrass flowers in response to vernalization and long-days, and VRN1 and FT1 homologs play key roles in each of these responses, respectively (Petersen et al., 2004; King et al., 2006). The perennial growth habit arises from the retention of vegetative meristems at the base of the plant during flowering, allowing vegetative growth to continue after a period of summer dormancy. It is not clear whether these buds do not respond to vernalization or whether there is a loss of the memory of vernalization.

Timothy grass is also a member of the core Pooideae that flowers in response to vernalization then long days (Seppänen et al., 2010). Unlike annual grasses, only a percentage of tillers flower in spring, allowing vegetative growth to continue even when some tillers flower. The reason why some tillers flower while others remain vegetative is unclear, but this is an important question for understanding the perennial growth habit of this grass. Timothy grass produces a second flush of elongating tillers in summer. Unlike the tillers produced in spring, the inflorescence of these tillers does not develop fully. Expression of VRN1 is activated by vernalization in the spring tillers but is not maintained in the summer tillers (Seppänen et al., 2010). This might be one reason that inflorescence development stalls in summer tillers. An inability to maintain VRN1 expression might also contribute to the perennial growth habit of timothy grass.

Another interesting finding from timothy grass is that expression of a VRN2-like gene increases as daylength increases following vernalization (Seppänen etal., 2010). This contrasts with the expression behavior of VRN2 in other core Pooideae, where VRN2 
is repressed following vernalization. A similar observation has been made in Brachypodium, where a VRN2-like gene is activated by long days in vernalized plants (Ream et al., 2014). Perhaps $V R N 2$-like genes have a broader role in perennial grasses to repress flowering in the long days of summer and to restore a vegetative growth habit before autumn.

\section{FUTURE DIRECTIONS}

The Pooideae are a worthwhile target for the study natural variation in seasonal flowering responses. There are large collections of different accessions from many Pooid species and this provides a rich source of genetic diversity, from wild species and domesticated crops. Rapidly developing genomic resources are allowing this diversity to be explored. Surveying diversity alone will not provide mechanistic insights into the molecular pathways controlling flowering or how variation in these pathways influences adaptation to different climates. The development and study of focussed genetic resources including mapping populations, near-isogenic lines, mutants, and transgenic plants will be a priority for future research, since these tools can resolve gene function and assess the impact of genetic variation.

Studying the molecular pathways controlling seasonal flowering responses in a broader range of Pooid species, particularly grasses outside the core Pooid group, will provide a clearer view of how these pathways evolved. Research in to basal Pooids, such as Stipa or Melica for example (Figure 4), might provide some indication of when the vernalization and long day flowering responses evolved during the radiation of the Pooideae. Additionally, a deeper understanding of the pathways controlling flowering in perennial Pooids can potentially offer further insights into the functions of key genes. Most importantly, ongoing research focussed directly on the Pooideae is essential if we are to develop a deeper understanding the reproductive biology of this important group of plants.

\section{AUTHOR CONTRIBUTIONS}

Siri Fjellheim, Scott Boden, and Ben Trevaskis wrote the manuscript.

\section{ACKNOWLEDGMENTS}

We thank the Norwegian Research Council and Nansen Foundation, and also the Australian Grains Research and Development Corporation (GRDC) and CSIRO for support of research in this area.

\section{REFERENCES}

Abe, M., Kobayashi, Y., Yamamoto, S., Daimon, Y., Yamaguchi, A., Ikeda, Y., et al. (2005). FD, a bZIP protein mediating signals from the floral pathway integrator FT at the shoot apex. Science 309, 1052-1056. doi: 10.1126/science.1115983

Allard, V., Veisz, O., Kõszegi, B., Rousset, M., Le Gouis, J., and Martre, P. (2012). The quantitative response of wheat vernalization to environmental variables indicates that vernalization is not a response to cold temperature. J. Exp. Bot. 63, 847-857. doi: 10.1093/jxb/err316

Alonso-Peral, M. M., Oliver, S. N., Casao, M. C., Greenup, A. A., and Trevaskis, B. (2011). The promoter of the cereal VERNALIZATION1 gene is sufficient for transcriptional induction by prolonged cold. PLOS ONE 6:e29456. doi: 10.1371/journal.pone.0029456

Amasino, R. (2010). Seasonal and developmental timing of flowering. Plant J. 61, 1001-1013. doi: 10.1111/j.1365-313X.2010.04148.x
Andersen, J. R., Jensen, L. B., Asp, T., and Lübberstedt, T. (2006). Vernalization response in perennial ryegrass (Lolium perenne L.) involves orthologues of diploid wheat (Triticum monococcum) VRN1 and rice (Oryza sativa) Hd1. Plant Mol. Biol. 60, 481-484. doi: 10.1007/s11103-005-4815-1

Asp, T., Byrne, S., Gundlach, H., Bruggmann, R., Mayer, K. F., Andersen, J. R., et al. (2011). Comparative sequence analysis of VRN1 alleles of Lolium perenne with the co-linear regions in barley, wheat, and rice. Mol. Genet. Genomics 286, 433-437. doi: 10.1007/s00438-011-0654-8

Balasubramanian, S., Sureshkumar, S., Lempe, J., and Weigel, D. (2006). Potent induction of Arabidopsis thaliana flowering by elevated growth temperature. PLoS Genet. 2:e106. doi: 10.1371/journal.pgen.0020106

Barnard, C. (1964). "Form and structure," in Grasses and Grasslands, ed. C. Barnard (New York: MacMillan), 47-72.

Bastow, R., Mylne, J. S., Lister, C., Lippman, Z., Martienssen, R. A., and Dean, C. (2004). Vernalization requires epigenetic silencing of FLC by histone methylation. Nature 427, 164-167. doi: 10.1038/nature02269

Beales, J., Turner, A., Griffiths, S., Snape, J., and Laurie, D. A. (2007). A pseudoresponse regulator is misexpressed in the photoperiod insensitive Ppd-Dla mutant of wheat (Triticum aestivum L.). Theor. Appl. Genet. 115, 721-733. doi: 10.1007/s00122-007-0603-4

Ben-Naim, O., Eshed, R., Parnis, A., Teper-Bamnolker, P., Shalit, A., Coupland, G., et al. (2006). The CCAAT binding factor can mediate interactions between CONSTANS-like proteins and DNA. Plant J. 46, 462-476. doi: 10.1111/j.1365313X.2006.02706.x

Blázquez, M. A., Ahn, J. H., and Weigel, D. (2003). A thermosensory pathway controlling flowering time in Arabidopsis thaliana. Nat. Genet. 33, 168-171. doi: $10.1038 / \mathrm{ng} 1085$

Boden, S. A., Weiss, D., Ross, J. J., Davies, N. W., Trevaskis, B., Chandler, P. M., et al. (2014). EARLY FLOWERING3 regulates flowering in spring barley by mediating gibberellin production and FLOWERING LOCUS T expression. Plant Cell 26, 1557-1569. doi: 10.1105/tpc.114.123794

Brown, H. E., Jamieson, P. D., Brooking, I. R., Moot, D. J., and Huth, N. I. (2013). Integration of molecular and physiological models to explain time of anthesis in wheat. Ann. Bot. 112, 1683-1703. doi: 10.1093/aob/mct224

Campoli, C., Pankin, A., Drosse, B., Casao, C., Davis, S. J., and von Korff, M. (2013). HvLUX1 is a candidate gene underlying the early maturity 10 locus in barley: phylogeny, diversity, and interactions with the circadian clock and photoperiodic pathways. New Phytol. 199, 1045-1059. doi: 10.1111/ nph.12346

Campoli, C., Shtaya, M., Davis, S. J., and von Korff, M. (2012). Expression conservation within the circadian clock of a monocot: natural variation at barley Ppd-H1 affects circadian expression of flowering time genes, but not clock orthologs. BMC Plant Biol. 12:97. doi: 10.1186/1471-2229-12-97

Cane, K., Eagles, H. A., Laurie, D. A., Trevaskis, B., Vallance, N., Eastwood, R. F., et al. (2013). Ppd-B1 and Ppd-D1 and their effects in southern Australian wheat. Crop Pasture Sci. 64, 100-114. doi: 10.1071/CP13086

Casao, M. C., Igartua, E., Karsai, I., Lasa, J. M., Gracia, M. P., and Casas, A. M. (2011). Expression analysis of vernalization and day-length response genes in barley (Hordeum vulgare L.) indicates that VRNH2 is a repressor of PPDH2 (HvFT3) under long days. J. Exp. Bot. 62, 1939-1949. doi: 10.1093/ jxb/erq382

Chen, A., and Dubcovsky, J. (2012). Wheat TILLING mutants show that the vernalization gene VRN1 down-regulates the flowering repressor VRN2 in leaves but is not essential for flowering. PLoS Genet. 8:e1003134. doi: 10.1371/journal.pgen.1003134

Chen, Y., Carver, B. F., Wang, S., Zhang, F., and Yan, L. (2009). Genetic loci associated with stem elongation and winter dormancy release in wheat. Theor. Appl. Genet. 118, 881-889. doi: 10.1007/s00122-008-0946-5

Chouard, P. (1960). Vernalization and its relations to dormancy. Annu. Rev. Plant Physiol. 11, 191-238. doi: 10.1146/annurev.pp.11.060160. 001203

Cockram, J., Chiapparino, E., Taylor, S., Stamati, K., Donini, P., Laurie, D., etal. (2007). Haplotype analysis of vernalization loci in European barley germplasm reveals novel VRN-H1 alleles and a predominant winter VRNH1/VRN-H2 multi-locus haplotype. Theor. Appl. Genet. 115, 993-1001. doi: 10.1007/s00122-007-0626-x

Comadran, J., Kilian, B., Russell, J., Ramsay, L., Stein, N., Ganal, M., et al. (2012). Natural variation in a homolog of Antirrhinum CENTRORADIALIS contributed 
to spring growth habit and environmental adaptation in cultivated barley. Nat. Genet. 44, 1388-1392. doi: 10.1038/ng.2447

Corbesier, L., Vincent, C., Jang, S. H., Fornara, F., Fan, Q. Z., Searle, I., et al. (2007). FT protein movement contributes to long distance signaling in floral induction of Arabidopsis. Science 316, 1030-1033. doi: 10.1126/science. 1141752

Danyluk, J., Kane, N. A., Breton, G., Limin, A. E., Fowler, D. B., and Sarhan, F. (2003). TaVRT-1, a putative transcription factor associated with vegetative to reproductive transition in cereals. Plant Physiol. 132, 1849-1860. doi: 10.1104/pp.103.023523

Davis, J. I., and Soreng, R. J. (1993). Phylogenetic structure in the grass family (Poaceae) as inferred from chloroplast DNA restriction site variation. Am. J. Bot. 80, 1444-1454. doi: 10.2307/2445674

Davis, J. I., and Soreng, R. J. (2007). A preliminary phylogenetic analysis of the grass subfamily Pooideae (Poaceae), with attention to structural features ofthe plastid and nuclear genomes, including an intron loss in GBSSI. Aliso 23, 335-348. doi: 10.5642/aliso.20072301.27

Díaz, A., Zikhali, M., Turner, A. S., Isaac, P., and Laurie, D. A. (2012). Copy number variation affecting the Photoperiod-B1 and Vernalization-A1 genes is associated with altered flowering time in wheat (Triticum aestivum). PLoS ONE 7:e33234. doi: 10.1371/journal.pone.0033234

Dubcovsky, J., Chen, C., and Yan, L. (2005). Molecular characterization of the allelic variation at the VRN-H2 vernalization locus in barley. Mol. Breed. 15, 395-407. doi: 10.1007/s11032-005-0084-6

Dubcovsky, J., Loukoianov, A., Fu, D., Valarik, M., Sanchez, A., and Yan, L. (2006) Effect of photoperiod on the regulation of wheat vernalization genes VRN1 and VRN2. Plant Mol. Biol. 60, 469-480. doi: 10.1007/s11103-005-4814-2

Ducrocq, S., Giauffret, C., Madur, D., Combes, V., Dumas, F., Jouanne, S., et al (2009). Fine mapping and haplotype structure analysis of a major flowering time quantitative trait locus on maize chromosome 10. Genetics 183, 1555-1563. doi: 10.1534/genetics.109.106922

Eagles, H. A., Cane, K., and Vallance, N. (2009). The flow of alleles of important photoperiod and vernalisation genes through Australian wheat. Crop Pasture Sci. 60, 646-657. doi: 10.1071/CP09014

Eagles, H. A., Cane, K., Trevaskis, B., Vallance, N., Eastwood, R. F., Gororo, N. N., et al. (2014). Ppd1, Vrn1, ALMT1 and Rht genes and their effects on grain yield in lower rainfall environments in southern Australia. Crop Pasture Sci. 65, 159-170. doi: $10.1071 / \mathrm{CP} 13374$

Ergon, A., Hamland, H., and Rognli, O. A. (2013). Differential expression of VRN1 and other MADS-box genes in Festuca pratensis selections with different vernalization requirements. Biol. Plant. 57: 245-254. doi: 10.1007/s10535-012-0283-z

Evans, L. T. (1964). "Reproduction," in Grasses and Grasslands, ed. C. Barnard (New York: MacMillan), 126-153.

Evans, L. T. (1980). Response to challenge: William Farrer and the making of wheats. J. Aust. Inst. Agric. Sci. 46, 3-13.

Evans, L. T. (1987). Short day induction of inflorescence initiation in some winter wheat varieties. Funct. Plant Biol. 14, 277-286. doi: 10.1071/ PP9870277

Evans, L. T., King, R. W., Chu, A., Mander, L. N., and Pharis, R. P. (1990). Gibberellin structure and florigenic activity in Lolium temulentum, a long-day plant. Planto 182, 97-106. doi: 10.1007/BF00239990

Faure, S., Higgins, J., Turner, A., and Laurie, D. A. (2007). The FLOWERING LOCUS T-like gene family in barley (Hordeum vulgare). Genetics 176, 599-609. doi: 10.1534/genetics.106.069500

Faure, S., Turner, A. S., Gruszka, D., Christodoulou, V., Davis, S. J., von Korff, M., et al. (2012). Mutation at the circadian clock gene EARLY MATURITY 8 adapts domesticated barley (Hordeum vulgare) to short growing seasons. Proc. Natl. Acad. Sci. U.S.A. 109, 8328-8333. doi: 10.1073/pnas. 1120496109

Fejer, S. O. (1966). Growth and reproduction of New Zealand Mediterranean and hybrid Dactylis glomerata after short day and temperature treatments. Can. J. Plant Sci. 46, 233-241. doi: 10.4141/cjps66-040

Finnegan, E. J., and Dennis, E. S. (2007). vernalization-induced trimethylation of histone H3 Lysine 27 at FLC is not maintained in mitotically quiescent cells. Curr. Biol. 17, 1978-1983. doi: 10.1016/j.cub.2007.10.026

Fowler, D. B., Breton, G., Limin, A. E., Mahfoozi, S., and Sarhan, F. (2001). Photoperiod and temperature interactions regulate low-temperature induced gene expression in barley. Plant Physiol. 127, 1676-1681. doi: 10.1104/pp.010483
Fowler, D. B., Chauvin, L. P., Limin, A. E., and Sarhan, F. (1996). The regulatory role of vernalization in the expression of low-temperature-induced genes in wheat and rye. Theor. Appl. Genet. 93, 554-559. doi: 10.1007/ BF00417947

Fu, D., Szucs, P., Yan, L., Helguera, M., Skinner, J. S., von Zitzewitz, J., et al. (2005). Large deletions within the first intron in VRN-1 are associated with spring growth habit in barley and wheat. Mol. Genet. Genomics 273, 54-65. doi: 10.1007/s00438004-1095-4

Gassner, G. (1918). Beitraege zur physiologischen charakteristik sommer und winterannueller gewaechse in besondere der getreidepflanzen. Z. Bot. 10, 27-476. doi: 10.1007/BF00709593

Gawroñski, P., Ariyadasa, R., Himmelbach, A., Poursarebani, N., Kilian, B., Stein, N., et al. (2014). A distorted circadian clock causes early flowering and temperaturedependent variation in spike development in the Eps-3Am mutant of einkorn wheat. Genetics 196, 1253-1261. doi: 10.1534/genetics.113.158444

Golovnina, K. A., Kondratenko, E. Y., Blinov, A. G., and Goncharov, N. P. (2010). Molecular characterization of vernalization loci VRN1 in wild and cultivated wheats. BMC Plant Biol. 10:168. doi: 10.1186/1471-2229-10-168

Gott, M. B., Gregory, F. G., and Purvis, O. N. (1955). Studies in vernalization of cereals VIII. photoperiodic control of stage in flowering between initiation and ear formation in vernalised and unvernalised petkus winter rye. Ann. Bot. 21, $87-126$.

Graf, A., and Smith, A. M. (2012). Starch and the clock: the dark side of plant productivity. Trends Plant Sci. 16, 169-175. doi: 10.1016/j.tplants.2010.12.003

Grass Phylogeny Working Group [GPWG] II. (2012). New grass phylogeny resolves deep evolutionary relationships and discovers C4 origins. New Phytol. 193, 304312. doi: 10.1111/j.1469-8137.2011.03972.x

Greenup, A., Peacock, W. J., Dennis, E. S., and Trevaskis, B. (2009). The molecular biology of seasonal flowering-responses in Arabidopsis and the cereals. Ann. Bot. 103, 1165-1172. doi: 10.1093/aob/mcp063

Greenup, A. G., Sasani, S., Oliver, S. N., Talbot, M. J., Dennis, E. S., Hemming, M. N., et al. (2010). ODDSOC2 is a MADS-box floral repressor that is downregulated by vernalization in temperate cereals. Plant Physiol. 153, 1062-1073. doi: 10.1104/pp.109.152488

Greenup, A. G., Sasani, S., Oliver, S. N., Walford, S. A., Millar, A. A., and Trevaskis, B. (2011). Transcriptome analysis of the vernalization response in barley (Hordeum vulgare) seedlings. PLoS ONE 6:e17900. doi: 10.1371/journal.pone.0017900

Hartley, W. (1973). Studies on origin, evolution, and distribution of Gramineae. V. Subfamily Festucoideae. Aust. J. Bot. 21, 201-234. doi: 10.1071/ BT9730201

Heide, O. M. (1994). Control of flowering and reproduction in temperate grasses. New Phytol. 128, 347-362. doi: 10.1111/j.1469-8137.1994.tb04019.x

Helliwell, C. A., Wood, C. C., Robertson, M., Peacock, W. J., and Dennis, E. S. (2006). The Arabidopsis FLC protein interacts directly in vivo with SOC1 and FT chromatin and is part of a high-molecular weight protein complex. Plant J. 46, 183-192. doi: 10.1111/j. 1365-313X. 2006. 02686.x

Hemming, M. N., Fieg, S., Peacock, W. J., Dennis, E. S., and Trevaskis, B. (2009). Regions associated with repression of the barley (Hordeum vulgare) VERNALIZATION1 gene are not required for cold induction. Mol. Genet. Genomics 282, 107-117. doi: 10.1007/s00438-009-0449-3

Hemming, M. N., Peacock, W. J., Dennis, E. S., and Trevaskis, B. (2008). Lowtemperature and daylength cues are integrated to regulate FLOWERING LOCUS $T$ in barley. Plant Physiol. 147, 355-366. doi: 10.1104/pp.108.116418

Hemming, M. N., Walford, S. A., Fieg, S., Dennis, E. S., and Trevaskis, B. (2012). Identification of high-temperature-responsive genes in cereals. Plant Physiol. 158, 1439-1450. doi: 10.1104/pp.111.192013

Hung, H. Y., Shannon, L. M., Tian, F., Bradbury, P. J., Chen, C., Flint-Garcia, S. A., et al. (2012). ZmCCT and the genetic basis of day-length adaptation underlying the postdomestication spread of maize. Proc. Natl. Acad. Sci. U.S.A. 109, E1913E1921. doi: 10.1073/pnas.1203189109

Jensen, L. B., Andersen, J. R., Frei, U., Xing, Y., Taylor, C., Holm, P. B., et al. (2005). QTL mapping of vernalization response in perennial ryegrass (Lolium perenne L.) reveals co-location with an orthologue of wheat VRN1. Theor. Appl. Genet. 110, 527-536. doi: 10.1007/s00122-004-1865-8

Jokela, V., Virkajärvi, P., Tanskanen, J., and Seppänen, M. M. (2013). Vernalization, gibberellic acid and photo period are important signals of yield formation in timothy (Phleum pratense). Physiol. Plant. doi: 10.1111/ppl.12141 [Epub ahead of print]. 
Jones, H., Civáň, P., Cockram, J., Leigh, F. J., Smith, L. M., Jones, M. K., et al. (2011). Evolutionary history of barley cultivation in Europe revealed by genetic analysis of extant landraces. BMC Evol. Biol. 11:320. doi: 10.1186/1471-2148-11-320

Kardailsky, I., Shukla, V. K., Ahn, J. H., Dagenais, N., Christensen, S. K., Nguyen, J. T., et al. (1999). Activation tagging of the floral inducer FT. Science 286, 1962-1965. doi: 10.1126/science.286.5446.1962

Karsai, I., Szûcs, P., Meszaros, K., Filichkina, T., Hayes, P. M., Skinner, J. S., etal. (2005). The Vrn-H2 locus is a major determinant of flowering time in a facultative $\mathrm{x}$ winter growth habit barley (Hordeum vulgare L.) mapping population. Theor. Appl. Genet. 110, 1458-1466. doi: 10.1007/s00122-0051979-7

Kikuchi, R., Kawahigashi, H., Ando, T., Tonooka, T., and Handa, H. (2009). Molecular and functional characterization of PEBP genes in barley reveal the diversification of their roles in flowering. Plant Physiol. 149, 1341-1353. doi: 10.1104/pp.108.132134

King, R. W., and Evans, L. T. (2003). Gibberellins and flowering of grasses and cereals: prizing open the lid of the "florigen" black box. Annu. Rev. Plant Biol. 54 307-328. doi: 10.1146/annurev.arplant.54.031902.135029

King, R. W., Moritz, T., Evans, L. T., Martin, J., Andersen, C. H., Blundell, C., et al. (2006). Regulation of flowering in the long-day grass Lolium temulentum by gibberellins and the FLOWERING LOCUS T gene. Plant Physiol. 141, 498-507. doi: 10.1104/pp.106.076760

Kobayashi, Y., Kaya, H., Goto, K., Iwabuchi, M., and Araki, T. (1999). A pair of related genes with antagonistic roles in mediating flowering signals. Science 286, 1960-1962. doi: 10.1126/science.286.5446.1960

Kuchel, H., Williams, K. J., Langridge, P., Eagles, H. A., and Jefferies, S. P. (2007) Genetic dissection of grain yield in bread wheat. I. QTL analysis. Theor. Appl. Genet. 115, 1015-1027. doi: 10.1007/s00122-007-0628-8

Kumar, S. V., Lucyshyn, D., Jaeger, K. E., Alós, E., Alvey, E., Harberd, N. P., et al. (2012). Transcription factor PIF4 controls thermosensory activation of flowering. Nature 484, 242-245. doi: 10.1038/nature10928

Lee, H., Suh, S. S., Park, E., Cho, E., Ahn, J. H., Kim, S. G., et al. (2000). The AGAMOUS-LIKE 20 MADS domain protein integrates floral inductive pathways in Arabidopsis. Genes Dev. 15, 2366-2376. doi: 10.1101/gad 813600

Lee, J. H., Ryu, H. S., Chung, K. S., Posé, D., Kim, S., Schmid, M., et al. (2013). Regulation of temperature-responsive flowering by MADS-box transcription factor repressors. Science 342, 628-632. doi: 10.1126/science.1241097

Li, C., Distelfeld, A., Comis, A., and Dubcovsky, J. (2011). Wheat flowering repressor VRN2 and promoter $\mathrm{CO}_{2}$ compete for interactions with NUCLEAR FACTOR-Y complexes. Plant J. 67, 763-773. doi: 10.1111/j.1365-313X.2011.04630.x

Li, C., and Dubcovsky, J. (2008). Wheat FT protein regulates VRN1 transcription through interactions with FDL2. Plant J. 55, 543-554. doi: 10.1111/j.1365313X.2008.03526.x

Limin, A. E., and Fowler, D. B. (2006). Low-temperature tolerance and genetic potential in wheat (Triticum aestivum $\mathrm{L}$.): response to photoperiod, vernalization, and plant development. Planta 224, 360-366. doi: 10.1007/s00425-006-0219-y

Loscos, J., Igartua, E., Contreras-Moreira, B., Gracia, M. P., and Casas, A. M. (2014). HvFT1 polymorphism and effect-survey of barley germplasm and expression analysis. Front. Plant Sci. 5:251. doi: 10.3389/fpls.2014.00251

Lundqvist, U. (2009). "Eighty years of Scandinavian barley mutation genetics and breeding," in Induced Plant Mutations in the Genomics Era, ed. Q. Y. Shu (Rome: Food and Agriculture Organization of the United Nations), 39-43.

Lv, B., Nitcher, R., Han, X., Wang, S., Ni, F., Li, K., et al. (2014). Characterization of FLOWERING LOCUS T1 (FT1) gene in Brachypodium and wheat. PLoS ONE 9:e94171. doi: 10.1371/journal.pone.0094171

MacMillan, C. P., Blundell, C. A., and King, R. W. (2005). Flowering of the grass Lolium perenne: effects of vernalization and long days on gibberellin biosynthesis and signaling. Plant Physiol. 138, 1794-1806. doi: 10.1104/pp.105.062190

Michaels, S. D., and Amasino, R. M. (1999). FLOWERING LOCUS C encodes a novel MADS domain protein that acts as a repressor of flowering. Plant Cell 11, 949-956. doi: 10.2307/3870827

Michaels, S. D., Himelblau, E., Kim, S. Y., Schomburg, F. M., and Amasino, R. M. (2005). Integration of flowering signals in winter-annual Arabidopsis. Plant Physiol. 137, 376-385. doi: 10.1104/pp.104.052811

Miralles, D. J., and Richards, R. A. (2000). Response of leaf and tiller emergence and primordium initiation in wheat and barley to interchanged photoperiod. Ann. Bot. 85, 655-663. doi: 10.1006/anbo.2000.1121
Mizuno, N., Nitta, M., Sato, K., and Nasuda, S. (2012). A wheat homologue of PHYTOCLOCK 1 is a candidate gene conferring the early heading phenotype to einkorn wheat. Genes Genet. Syst. 87, 357-367. doi: 10.1266/ggs.87.357

Murai, K., Miyamae, M., Kato, H., Takumi, S., and Ogihara, Y. (2003). WAP1, a wheat APETALA1 homolog, plays a central role in the phase transition from vegetative to reproductive growth. Plant Cell Physiol. 44, 1255-1265. doi: 10.1093/pcp/pcg171

Nishida, H., Yoshida, T., Kawakami, K., Fujita, M., Long, B., Akashi, Y., et al. (2013). Structural variation in the $5^{\prime}$ upstream region of photoperiod-insensitive alleles Ppd-Ala and Ppd-Bla identified in hexaploid wheat (Triticum aestivum L.), and their effect on heading time. Mol. Breed. 31, 27-37. doi: 10.1007/s11032-0129765-0

Nitcher, R., Distelfeld, A., Tan, C., Yan, L., and Dubcovsky, J. (2013). Increased copy number at the HvFT1 locus is associated with accelerated flowering time in barley. Mol. Genet. Genomics 288, 261-275. doi: 10.1007/s00438-0130746-8

Oliver, S. N., Deng, W., Casao, M. C., and Trevaskis, B. (2013). Low temperatures induce rapid changes in chromatin state and transcript levels of the cereal VERNALIZATION1 gene. J. Exp. Bot. 64, 2413-2422. doi: 10.1093/jxb/ ert095

Oliver, S. N., Finnegan, E. J., Dennis, E. S., Peacock, W. J., and Trevaskis, B. (2009). Vernalization-induced flowering in cereals is associated with changes in histone methylation at the VERNALIZATION1 gene. Proc. Natl. Acad. Sci. U.S.A. 106, 8386-8391. doi: 10.1073/pnas.0903566106

Ortiz-Marchena, M. I., Albi, T., Lucas-Reina, E., Said, F. E., Romero-Campero, F. J., Cano, B., etal. (2014). Photoperiodic control of carbon distribution during the floral transition in Arabidopsis. Plant Cell 26, 565-584. doi: $10.1105 /$ tpc.114.122721

Pearce, S., Vanzetti, L. S., and Dubcovsky, J. (2013). Exogenous gibberellins induce wheat spike development under short days only in the presence of VERNALIZATION1. Plant Physiol. 163, 1433-1445. doi: 10.1104/pp.113. 225854

Petersen, K., Didion, T., Andersen, C. H., and Nielsen, K. K. (2004). MADSbox genes from perennial ryegrass differentially expressed during transition from vegetative to reproductive growth. J. Plant Physiol. 161, 439-447. doi: 10.1078/0176-1617-01212

Posé, D., Verhage, L., Ott, F., Yant, L., Mathieu, J., Angenent, G. C., et al. (2013). Temperature-dependent regulation of flowering by antagonistic FLM variants. Nature 503, 414-417. doi: 10.1038/nature12633

Preston, J. C., and Kellogg, E. A. (2008). Discrete developmental roles for temperate cereal grass VERNALIZATION1/FRUITFULL-Like genes in flowering competency and the transition to flowering. Plant Physiol. 146, 265-276. doi: 10.1104/pp.107.109561

Purvis, O. N. (1934). An analysis of the influence of temperature during germination on the subsequent development of certain winter cereals and its relation to the effect of length of day. Ann. Bot. 48, 919-955.

Purvis, O. N., and Gregory, F. G. (1937). Studies in vernalisation of cereals. Ann. Bot. 1, 1-26.

Rawson, H. M., and Richards, R. A. (1993). Effects of high temperature and photoperiod on floral development in wheat isolines differing in vernalisation and photoperiod genes. Field Crops Res. 32, 181-192. doi: 10.1016/03784290(93)90030-Q

Ream, T. S., Woods, D. P., Schwartz, C. J., Sanabria, C. P., Mahoy, J. A., Walters, E. M., et al. (2014). Interaction of photoperiod and vernalization determines flowering time of Brachypodium distachyon. Plant Physiol. 164, 694-709. doi: 10.1104/pp.113.232678

Reynolds, M., Foulkes, M. J., Slafer, G. A., Berry, P., Parry, M. A., Snape, J. W., et al. (2009). Raising yield potential in wheat. J. Exp. Bot. 60, 1899-1918. doi: 10.1093/jxb/erp016

Richardson, J. M., Morrow, L. A., and Gealy, D. R. (1986). Floral induction of downy brome (Bromus tectorum) as influenced by temperature and photoperiod. Weed Sci. 34, 698-703.

Ruelens, P., de Maagd, R. A., Proost, S., Theissen, G., Geuten, K., and Kaufmann, K. (2013). FLOWERING LOCUS $C$ in monocots and the tandem origin of angiosperm-specific MADS-box genes. Nat. Commun. 4, 1-8. doi: $10.1038 /$ ncomms 3280

Sampson, D. R., and Burrows, V. D. (1972). Influence of photoperiod, short-day vernalization, and cold vernalization on days to heading in Avena species and cultivars. Can. J. Plant Sci. 52, 471-482. doi: 10.4141/cjps72-077 
Sandve, S. R., Kosmala, A., Rudi, H., Fjellheim, S., Rapacz, M., Yamada, T., et al. (2011). Molecular mechanisms underlying frost tolerance in perennial grasses adapted to cold climates. Plant Sci. 180, 69-77. doi: 10.1016/j.plantsci.2010. 07.011

Sasani, S., Hemming, M. N., Oliver, S. N., Greenup, A., Tavakkol-Afshari, R., Mahfoozi, S., et al. (2009). The influence of vernalization and daylength on expression of flowering-time genes in the shoot apex and leaves of barley (Hordeum vulgare). J. Exp. Bot. 60, 2169-2178. doi: 10.1093/jxb/erp098

Schneider, J., Doring, E., Hilu, K. W., and Roser, M. (2009). Phylogenetic structure of the grass subfamily Pooideae based on comparison of plastid matK gene- $3^{\prime}$ trnK exon and nuclear ITS sequences. Taxon 58, 405-424.

Schubert, D., Primavesi, L., Bishopp, A., Roberts, G., Doonan, J., Jenuwein, T., et al. (2006). Silencing by plant Polycomb-group genes requires dispersed trimethylation of histone $\mathrm{H} 3$ at lysine 27. EMBO J. 25, 4638-4649. doi: 10.1038/sj.emboj.7601311

Schwartz, C. J., Doyle, M. R., Manzaneda, A. J., Rey, P. J., Mitchell-Olds, T., and Amasino, R. M. (2010). Natural variation of flowering time and vernalization responsiveness in Brachypodium distachyon. Bioenergy Res. 3, 38-46. doi: 10.1007/s12155-009-9069-9063

Seppänen, M. M., Pakarinen, K., Jokela, V., Andersen, J. R., Fiil, A., Santanen, A., et al. (2010). Vernalization response of Phleum pratense and its relationships to stem lignification and floral transition. Ann. Bot. 106, 697-707. doi: $10.1093 / \mathrm{aob} / \mathrm{mcq} 174$

Shaw, L. M., Turner, A. S., Herryl, L., Griffiths, S., and Laurie, D. A. (2013). Mutant alleles of Photoperiod-1 in wheat (Triticum aestivum L.) that confer a late flowering phenotype in long days. PLoS ONE 8:e79459. doi: 10.1371/journal.pone.0079459

Shaw, L. M., Turner, A. S., and Laurie, D. A. (2012). The impact of photoperiod insensitive Ppd-1a mutations on the photoperiod pathway across the three genomes of hexaploid wheat (Triticum aestivum). Plant J. 71, 71-84. doi: 10.1111/j.1365-313X.2012.04971.x

Sheldon, C. C., Burn, J. E., Perez, P. P., Metzger, J., Edwards, J. A., Peacock, W. J., et al. (1999). The FLF MADS box gene: a repressor of flowering in Arabidopsis regulated by vernalization and methylation. Plant Cell 11, 445-458. doi: 10.2307/ 3870872

Shimada, S., Ogawa, T., Kitagawa, S., Suzuki, T., Ikari, C., Shitsukawa, N., et al. (2009). A genetic network of flowering-time genes in wheat leaves, in which an APETALA1/FRUITFULL-like gene, VRN1, is upstream of FLOWERING LOCUS T. Plant J. 58, 668-681. doi: 10.1111/j.1365-313X.2009. 03806.x

Shinozuka, H., Hand, M. L., Cogan, N. O., Spangenberg, G. C., and Forster, J. W. (2013). Nucleotide diversity of vernalization and flowering-time-related genes in a germplasm collection of meadow fescue (Festuca pratensis Huds. syn. Lolium pratense (Huds.) Darbysh.). Evol. Ecol. 3, 4415-4426. doi: 10.1002/ ece3.828

Simpson, G. G. (2003). Evolution of flowering in response to day length: flipping the CONSTANS switch. Bioessays 25, 829-832. doi: 10.1002/ bies. 10330

Skøt, L., Sanderson, R., Thomas, A., Skøt, K., Thorogood, D., Latypova, G., et al. (2011). Allelic variation in the perennial ryegrass FLOWERING LOCUS T gene is associated with changes in flowering time across a range of populations. Plant Physiol. 155, 1013-1022. doi: 10.1104/pp.110.169870

Soreng, R. J., Davidse, G., Peterson, P. M., Zuloaga, F. O., Judziewicz, E. J., Filgueiras, T. S., et al. (2000). Classification of New World Grasses (Poaceae/Gramineae) Available at: http://www.tropicos.org/projectwebportal.aspx?pagename=Classi ficationNWG\&projectid $=10$

Stelmakh, A. F. (1993). Genetic effects of Vrn genes on heading date and agronomic traits in bread wheat. Euphytica 65, 53-60. doi: 10.1007/BF00022199

Stockinger, E. J., Skinner, J. S., Gardner, K. G., Francia, E., and Pecchioni, N. (2007). Expression levels of barley Cbf genes at the Frost resistance-H2 locus are dependent upon alleles at Fr-H1 and Fr-H2. Plant J. 51, 308-321. doi: 10.1111/j.1365-313X.2007.0141.x

Suarez-Lopez, P., Wheatley, K., Robson, F., Onouchi, H., Valverde, F., and Coupland, G. (2001). CONSTANS mediates between the circadian clock and the control of flowering in Arabidopsis. Nature 410, 1116-1120. doi: 10.1038/ 35074138

Szûcs, P., Skinner, J. S., Karsai, I., Cuesta-Marcos, A., Haggard, K. G., Corey, A. E., et al. (2007). Validation of the VRN-H2/VRN-H1 epistatic model in barley reveals that intron length variation in VRN-H1 may account for a continuum of vernalization sensitivity. Mol. Genet. Genomics 277, 249-261. doi: 10.1007/s00438-006-0195-8

Takahashi, R., and Yasuda, S. (1971). "Genetics of earliness and growth habit in barley," in Barley Genetics II. Proceeding of 2nd International Barley Genetics Symposium, ed. R. A. Nilan (Pullman: Washington State University Press), 388-408.

Tamaki, S., Matsuo, S., Wong, H. L., Yokoi, S., and Shimamoto, K. (2007). $\mathrm{Hd} 3 \mathrm{a}$ protein is a mobile flowering signal in rice. Science 316, 1033-1036. doi: 10.1126/science. 1141753

Thines, B. C, Youn, Y., Duarte, M. I., and Harmon, F. G. (2014). The time of day effects of warm temperature on flowering time involve PIF4 and PIF5. J. Exp. Bot. 65, 1141-1151. doi: 10.1093/jxb/ert487

Thomashow, M. F. (2010). Molecular basis of plant cold acclimation: insights gained from studying the CBF cold response pathway. Plant Physiol. 154, 571-577. doi: $10.1104 /$ pp.110.161794

Trevaskis, B. (2010). The central role of the VERNALIZATION1 gene in the vernalization response of cereals. Funct. Plant Biol. 37, 479-487. doi: 10.1071/ FP10056

Trevaskis, B., Bagnall, D. J., Ellis, M. H., Peacock, W. J., and Dennis, E. S. (2003). MADS box genes control vernalization-induced flowering in cereals. Proc. Natl. Acad. Sci. U.S.A. 100, 13099-13104. doi: 10.1073/pnas.1635053100

Trevaskis, B., Hemming, M. N., Dennis, E. S., and Peacock, W. J. (2007). The molecular basis of vernalization-induced flowering in cereals. Trends Plant Sci. 12, 352-357. doi: 10.1016/j.tplants.2007.06.010

Trevaskis, B., Hemming, M. N., Peacock, W. J., and Dennis, E. S. (2006). HvVRN2 responds to day length, whereas HvVRN1 is regulated by vernalization and developmental status. Plant Physiol. 140, 1397-1405. doi: 10.1104/pp.105. 073486

Turck, F., Fornara, F., and Coupland, G. (2008). Regulation and identity of florigen: FLOWERING LOCUS T moves center stage. Annu. Rev. Plant Biol. 59, 573-594. doi: 10.1146/annurev.arplant.59.032607.092755

Turner, A., Beales, J., Faure, S., Dunford, R. P., and Laurie, D. A. (2005). The pseudoresponse regulator $\mathrm{Ppd}-\mathrm{H} 1$ provides adaptation to photoperiod in barley. Science 310, 1031-1034. doi: 10.1126/science.1117619

Turner, A. S., Faure, S., Zhang, Y., and Laurie, D. A. (2013). The effect of dayneutral mutations in barley and wheat on the interaction between photoperiod and vernalization. Theor. Appl. Genet. 126, 2267-2277. doi: 10.1007/s00122-0132133-6

Valverde, F., Mouradov, A., Soppe, W., Ravenscroft, D., Samach, A., and Coupland, G. (2004). Photoreceptor regulation of CONSTANS protein in photoperiodic flowering. Science 303, 1003-1006. doi: 10.1126/science. 1091761

von Zitzewitz, J., Szûcs, P., Dubcovsky, J., Yan, L. L., Francia, E., Pecchioni, N., etal. (2005). Molecular and structural characterization of barley vernalization genes. Plant Mol. Biol. 59, 449-467. doi: 10.1007/s11103-0050351-2

Watson, L., and Dallwitz, M. J. (1992 onwards). The Grass Genera of the World: Descriptions, Illustrations, Identification, and Information Retrieval; Including Synonyms, Morphology, Anatomy, Physiology, Phytochemistry, Cytology, Classification, Pathogens, World and Local Distribution, and References. Version: 5th February 2014. Available at: http://delta-intkey.com

Wenkel, S., Turck, F., Singer, K., Gissot, L., Le Gourrierec, J., Samach, A., et al. (2006). CONSTANS and the CCAAT box binding complex share a functionally important domain and interact to regulate flowering of Arabidopsis. Plant Cell 18, 2971-2984. doi: 10.1105/tpc.106.043299

Wigge, P. A. Kim, M. C., Jaeger, K. E., Busch, W., Schmid, M., Lohmann, J. U., et al. (2005). Integration of spatial and temporal information during floral induction in Arabidopsis. Science 309, 1056-1059. doi: 10.1126/science.1114358

Wilhelm, E. P., Turner, A. S., and Laurie, D. A. (2009). Photoperiod insensitive PpdAla mutations in tetraploid wheat (Triticum durum Desf.). Theor. Appl. Genet. 118, 285-294. doi: 10.1007/s00122-008-0898-9

Wu, L., Liu, D., Wu, J., Zhang, R., Qin, Z., Liu, D., et al. (2013). Regulation of FLOWERING LOCUS T by a microRNA in Brachypodium distachyon. Plant Cell 25, 4363-4377. doi: 10.1105/tpc.113.118620

$\mathrm{Wu}, \mathrm{Z}$. Q., and Ge, S. (2012). The phylogeny of the BEP clade in grasses revisited: evidence from the whole-genome sequences of chloroplasts. Mol. Phylogenet. Evol. 62, 573-578. doi: 10.1016/j.ympev. 2011.10.019 
Xue, W., Xing, Y., Weng, X., Zhao, Y., Tang, W., Wang, L., et al. (2008). Natural variation in Ghd7 is an important regulator of heading date and yield potential in rice. Nat. Genet. 40, 761-767. doi: 10.1038/ ng. 143

Yan, L., Fu, D., Li, C., Blechl, A., Tranquilli, G., Bonafede, M., et al. (2006). The wheat and barley vernalization gene VRN3 is an orthologue of FT. Proc. Natl. Acad. Sci. U.S.A. 103, 19581-19586. doi: 10.1073/pnas.0607142103

Yan, L., Loukoianov, A., Blechl, A., Tranquilli, G., Ramakrishna, W., SanMiguel, P., et al. (2004a). The wheat VRN2 gene is a flowering repressor down-regulated by vernalization. Science 303, 1640-1644. doi: 10.1126/science. 1094305

Yan, L., Helguera, M., Kato, K., Fukuyama, S., Sherman, J., and Dubcovsky, J. (2004b). Allelic variation at the VRN-1 promoter region in polyploid wheat. Theor. Appl. Genet. 109, 1677-1686. doi: 10.1007/s00122-004-1796-4

Yan, L., Loukoianov, A., Tranquilli, G., Helguera, M., Fahima, T., and Dubcovsky, J. (2003). Positional cloning of the wheat vernalization gene VRN1. Proc. Natl. Acad. Sci. U.S.A. 100, 6263-6268. doi: 10.1073/pnas.0937399100

Yang, S., Weers, B. D., Morishige, D. T., and Mullet, J. E. (2014). CONSTANS is a photoperiod regulated activator of flowering in sorghum. BMC Plant Biol. 14:148. doi: 10.1186/1471-2229-14-148

Zakhrabekova, S., Gough, S. P., Braumann, I., Müller, A. H., Lundqvist, J., Ahmann, K., et al. (2012). Induced mutations in circadian clock regulator Mat-a facilitated short-season adaptation and range extension in cultivated barley. Proc. Natl. Acad. Sci. U.S.A. 109, 4326-4331. doi: 10.1073/pnas.1113009109

Zhang, J., Wang, Y., Wu, S., Yang, J., Liu, H., and Zhou, Y. (2012). A single nucleotide polymorphism at the Vrn-D1 promoter region in common wheat is associated with vernalization response. Theor. Appl. Genet. 125, 1697-1704. doi: $10.1007 /$ s00122-012-1946-z
Zhao, L., Zhang, N., Ma, P. F., Liu, Q., Li, D. Z., and Guo, Z. H. (2013). Phylogenomic analyses of nuclear genes reveal the evolutionary relationships within the BEP clade and the evidence of positive selection in Poaceae. PLoS ONE 8:e64642. doi: 10.1371/journal.pone.0064642

Zhu, J., Pearce, S., Burke, A., See, D. R., Skinner, D. Z., Dubcovsky, J., etal. (2014). Copy number and haplotype variation at the VRN-Al and central FR-A2 loci are associated with frost tolerance in hexaploid wheat. Theor. Appl. Genet. 127, 1183-1197. doi: 10.1007/s00122-0142290-2

Conflict of Interest Statement: The authors declare that the research was conducted in the absence of any commercial or financial relationships that could be construed as a potential conflict of interest.

Received: 29 June 2014; paper pending published: 28 July 2014; accepted: 13 August 2014; published online: 29 August 2014.

Citation: Fjellheim S, Boden S and Trevaskis B (2014) The role of seasonal flowering responses in adaptation of grasses to temperate climates. Front. Plant Sci. 5:431. doi: 10.3389/fpls.2014.00431

This article was submitted to Plant Genetics and Genomics, a section of the journal Frontiers in Plant Science.

Copyright (c) 2014 Fjellheim, Boden and Trevaskis. This is an open-access article distributed under the terms of the Creative Commons Attribution License (CC BY). The use, distribution or reproduction in other forums is permitted, provided the original author(s) or licensor are credited and that the original publication in this journal is cited, in accordance with accepted academic practice. No use, distribution or reproduction is permitted which does not comply with these terms. 